\title{
Small-Molecule Ligands as Challenge for Positron Emission Tomography of Peptide Receptors in Neurons and Microglia of the Brain
}

\section{Margit Pissarek}

Forschungszentrum Jülich GmbH, Institute of Neuroscience and Medicine, INM-5 Nuclear Chemistry, Jülich, Germany Email: m.pissarek@fz-juelich.de

How to cite this paper: Pissarek, M. (2019) Small-Molecule Ligands as Challenge for Positron Emission Tomography of Peptide Receptors in Neurons and Microglia of the Brain. World Journal of Neuroscience, 9, 294-327.

https://doi.org/10.4236/wjns.2019.94022

Received: September 9, 2019

Accepted: November 26, 2019

Published: November 29, 2019

This work is licensed under the Creative Commons Attribution-NonCommercial International License (CC BY-NC 4.0). http://creativecommons.org/licenses/by-nc/4.0/ 운 $\$$ Open Access

\begin{abstract}
Neuropeptide and chemokine receptors of the G protein-coupled receptor (GPCR) family belong to different classes and subgroups providing different docking sites and special binding behavior at extracellular and also transmembrane domains for small molecules potentially suitable for positron emission tomography (PET). The contribution gives an overview updating developments of small-molecule, nonpeptide ligands at a selection of peptide and chemokine receptors, expressed in neurons and microglia of the brain, regarding the last five years. Orexin 1 and orexin 2 receptors (OX1R; OX2R) and neuropeptide Y1 and Y2 receptors (NPY1R, NPY2R) were chosen as representatives of Class A neuropeptide receptors, chemokine receptor CX3C (CX3CR1) as Class A, protein-activated receptor, highly expressed in activated microglia, and corticotropin releasing factor receptor 1 (CRFR1) as representative Class B1 receptor. Structural differences between binding domains and their endogenous ligands as well as parallel expression in different types of cells and generally low density of these receptors in brain tissue are factors making the search for selective and sensitive ligands more difficult than for classical GPCR receptors. Main progress in ligand development is observed for NPY receptor antagonists and orexin receptor antagonists. For orexin receptors, search for suitable ligands can be supported with modelling approaches, as recently the complete molecular structure of these receptors is available. Small molecules, binding at CRFR1, as for other Class B1 receptor ligands, in PET and investigations of pharmacodynamics revealed rather allosteric binding modes, although, the complete crystal structure of CRFR1 as prototype of Class B1 provides, hitherto, improved possibilities for understanding binding mechanisms. Highly specific as a marker of microglia among
\end{abstract}


the GPCRs, CX3CR1 is focused as target of PET during inflammation of brain and spinal cord.

\section{Keywords}

Positron Emisson Tomography, Brain, Small-Molecule Ligand, Peptide Receptors, Neuron, Microglia

\section{Introduction}

Targeting 7TM receptors or G protein-coupled receptors (GPCR) belongs to the most successful pharmacological concepts in development of therapeutics with non-antibiotic clinical applications [1] [2] [3]. Although approximately $30 \%$ of clinically employed drugs target GPCR or GPCR-mediated pathways [4], to date, therapeutically effective small-molecule pharmaceuticals have been introduced for only 5\% - 10\% of all GPCR known [3] [5]. The plurality of all GPCRs is olfactory or sensory receptors. Among the 398 non-olfactory receptors, however, 224 are not in scope of clinical trials or efforts of drug development [3] [6].

Correspondingly, targets of PET tracers are in many of the cases 7TM receptors. Beside the classical receptors of the amine cluster also neuropeptide receptors move more and more in the focus of ligand development for therapy and diagnostics [3]. Differences in the structure of the $\mathrm{N}$ terminal ectodomains in the general binding behavior at receptors of various GPCR classes and possibilities for allosteric ligands gain rising attention [3] [4] [7] [8]. For PET, also the potential contribution of important cell populations like microglia and the search for cell specific radio-biomarkers became challenging questions. In primary cortical rat cell cultures mixed cellular population with $50 \%$ neurons, $20 \%$ astrocytes and 30\% CD11-labelled microglia have been described [9] (Table 1). Microglia include $0.5 \%$ - $16 \%$ of the human brain cells depending on the respective region of the brain [10], and in rodents $5 \%-12 \%$.

Microglias, as resident immune cells of the brain, are the pendant of peripheral macrophages and can be classified with current methods using a signature of histological markers as surveilling, pro-inflammatory (M1) and anti-inflammatory (M2) phenotypes [24] [25]. However, the variability of subgroups of microglia reflected by different fingerprints or sensoms/transcriptomes [26] [27] is even broader [28] [29].

Sellgren et al. [30], currently, demonstrated reduced density of synapses of schizophrenic patients due to a potentially higher pruning activity of microglial cells in such patient, with postmortem data.

Furthermore, the recent rescaling of contributions of the different cell types of the brain [13] [14] [15] [31] [32] might have also an impact on the role of microglia between the region-specific cell populations with more (cerebellum) or less (cortex) neuronal cells [15]. Other interesting fields are the presence of mi- 
croglia in neurogenic niches, the possibilities of transformation of brain cells and opportunities of support of tissue repair by transplantation of microglia in selected brain regions or spinal cord [33] [34] [35]. Moreover, it is not finally clear if the dogma is true that microglia population of the brain recruits new cells only from itself. For instance, Özen et al. postulated 2014 related to experiments in mice that also pericytes can be progenitor cells of cerebral microglia [36]. Furthermore, exit of microglia from and return to spinal cord had been reported in an experimental mouse model resulting in changed, "peripherally experienced" microglia cells in the spinal cord tissue [34].

Among the GPCR receptors mentioned as markers of microglia are the purine receptor P2Y12 [37] [38] and the chemokine receptor CX3CR1 (fractalkine receptor) [16] [39], both Class A GPCR [40] [41]. Only for CX3CR1, a first ligand labelled with the positron emitter fluorine-18 was tested [42] [43]. Also other peptide receptors expressed in neurons as well as in microglia [26] are poorly accessible with PET tools in vivo. PET identification of microglia has been performed, predominantly, with ligands of the mitochondrial $18 \mathrm{kDa}$ translocator protein 1 (TSPO1) [35] [44].

Different histological fingerprints have been shown also for cerebral and cerebellar microglia [45] and it is presumed that potential tracers can better achieve cellular populations of the spinal cord than of the brain due to differences between blood brain barrier (BBB) and blood spinal cord barrier (BSCB) [46].

Table 1. Selected reports on cellular rescaling of the brain and on microglial neuropeptide receptors.

\begin{tabular}{|c|c|c|c|c|}
\hline \multicolumn{5}{|c|}{ Selected Reports on Cellular Distribution and Expression of Microglial Neuropeptide Receptors in the Brain } \\
\hline Model & Species & Cellular or Receptor Distribution & Method & References \\
\hline $\begin{array}{l}\text { Mixed primary rat neuronal } \\
\text { cortical culture }\end{array}$ & Rat & $\begin{array}{l}50 \% \text { neurons } \\
20 \% \text { astrocytes } \\
\text { Remaining part: microglia }(\mathrm{CD} 11)\end{array}$ & Immuno-histochemichal & [9] \\
\hline Whole brain & Human & $\begin{array}{l}0.5 \%-16 \% \text { microglia } \\
\text { In white matter }>\text { in gray matter }\end{array}$ & Immuno-histochemical & [10] [11] \\
\hline Whole brain & Rodent & $\begin{array}{l}15 \%-12 \% \text { microglia } \\
\text { In gray matter }>\text { in white matter }\end{array}$ & Immuno-histochemical & [10] [12] \\
\hline $\begin{array}{l}\text { Cellular nuclei } \\
\text { Cortex ( } 82 \% \text { of brain mass) } \\
\text { Cerebellum } \\
\text { ( } 10 \% \text { of brain mass })\end{array}$ & Human & $\begin{array}{l}50 \% \text { neuronal } \\
50 \% \text { nonneuronal } \\
19 \% \text { of total brain cells: neurons } \\
\text { Ca. } 80 \% \text { of total brain cells: nonneuronal cells } \\
80 \% \text { of total brain cells: neurons }\end{array}$ & Isotropic fractionation & [13] [14] [15] \\
\hline $\begin{array}{l}\text { Enriched glia and neuronal } \\
\text { culture }\end{array}$ & Rat & $\begin{array}{l}10 \text { fold in microglia vs. neurons or astrocytes } \\
\text { and macrophages }\end{array}$ & CX3CR mRNA & [16] [17] \\
\hline $\begin{array}{l}\text { Normal brain and spinal cord } \\
\text { Traumatic brain injury }\end{array}$ & $\begin{array}{l}\text { Rat } \\
\text { Mice }\end{array}$ & $\begin{array}{l}\text { OX1R } \\
\text { OX1R }\end{array}$ & $\begin{array}{l}\text { OX1R antibody } \\
\text { OX1R mRNA } \\
\text { OX1R antibody }\end{array}$ & $\begin{array}{l}{[18]} \\
{[19]}\end{array}$ \\
\hline Retinal Microglia , N9 & Rat & NPY1R, NPY2R & NPY1R mRNA, protein & [20] [21] [22] \\
\hline Spinal cord injury, microglia & Rat & CRFR1, CRFR2 & $\begin{array}{l}\text { CRFR1 antibody } \\
\text { CRFR2 antibody }\end{array}$ & [23] \\
\hline
\end{tabular}


Neuropeptides, binding to Class A or Class B1/Secretin GPCR family, are comprised of $<50$ a.a.r. [8] [47], whereas chemokines, relevant also for the CX3CR1, are proteins between 60 to 110 a.a.r. [48]. While there is a relatively large number of orthosteric/competitive antagonist or ligands of Class A receptor, smallmolecule, nonpeptide/nonprotein candidate compounds targeting Class B1 receptors or chemokine receptors are rather allosteric ligands [42] [44] [47] [49] [50].

Efforts in the development of novel small-molecule ligands are directed also to some neuropeptide receptors of both classes of GPCRs identified either expressed in neurons and in microglia, simultaneously, or predominantly in activated microglia, during the last decade. The chemokine receptor accepted as one of the biomarkers of activated microglia is CX3CR1 [17] [51] [52] [53]. It can be enhanced by the tenfold in diverse inflammatory processes in comparison to macrophages, neurons or astrocytes [16]. The extent of expression of CX3CR1 has been determined, predominantly, with mRNA measurements [20]. Further representatives of Class A receptors, however, with neuropeptides as endogenous ligands and small-molecule candidates for positron emission tomography (PET) imaging are the neuropeptide Y1 (NPY1) and neuropeptide Y2 (NPY2) receptors for which quantitative data on receptor density (receptor protein) in the brain are available [54] [55]. Expression in microglia has been reported [21] even if the percentage of contributions to PET images or in specific brain regions and the quantitative data on the degree of expression of the receptor proteins in comparison to neurons are yet not available. Orexin receptors, also Class A GPCRs, belong to the more than 40 receptors, in which the $3 \mathrm{D}$ crystal structure has been ascertained [48], meanwhile. Whereas the orexin 1 receptor (OX1R) seems to be expressed relatively specific in the brain and spinal cord [18], the main attention in research on orexin receptors is directed to orexin 2 receptors with view to its role in wake-sleep cycle and the therapeutic application of receptor antagonists in insomnia which get increasing attention, especially, because of strong adverse effects of the so called Z-drugs (like zolpidem) [56] [57]. Applications, especially for potential OX1R PET tracers, could be identified in traumatically injured brain tissue due to increased migration of microglia [19].

One of the Class B GPCRs investigated, already, for their potency in brainPET are the corticotropin releasing factor receptors (CRFR), where the first smallmolecule compound tested in vivo was a CRFR1 ligand [58]. CRF1R is regarded as the prototype for molecular modelling studies in Class B1 neuropeptide receptors with a crystal structure completely known, today [59] [60] [61]. This contribution compares small-molecule lead structures disclosed during the last decade as potential receptor ligands and possible approaches for development of pharmacophores with focus on NPY1 and 2 receptors, orexin 1 and 2 receptors, CRFR1 and the chemokine receptor CX3CR1 as well as the possibilities suggested by new recognitions and challenges on cellular subtypes and their distributions in brain and spinal cord [62]. 


\section{NPY-Receptors}

NPY receptor subtypes with relatively high density in some brain regions as well as in spleen, liver, gastrointestinal tract, blood vessels and fat cells [63] are also a target for brainPET ligands demonstrated, already, for NPY1, NPY2 and NPY5 receptors. However, most studies drew conclusions for receptors localized in neurons and the access to quantitative data on microglia had been, usually, complicated because of problems in comparability of reference parameters [20] [21] [22] and report of data as changes in percentage or without tissue or membrane protein reference, normally used for quantification of receptor occupancy.

The NPY1 receptor is one of the most abundant peptide receptors in the brain. Involvement of NPY1 receptors into inflammatory reactions of microglial cells has been confirmed e.g. by cellular and mouse models (like EAE encephalitis model) using lipopolysaccharides, well known as stimulatory compounds corresponding to components of the wall of gram-negative bacteria. A cascade of co-operative actions with ATP and activated interleukin- $1 \beta$ (IL-1 $\beta$ ) is presumed to stimulate p38 and mitogen-activated kinase in promotion of microglia motility [22] [64]. This reaction can be stopped by NPY1 antagonists [22]. Such approaches can be of interest also in the context of spinal cord injury and involvement of microglia in occurrence of neuropathic pain or inflammatory phase of diseases [22] [64].

Trials by Hostetler et al. (Merck) resulted in first PET distribution maps in brain monkey using the small molecule Y-973 ( $\mathrm{IC}_{50}$ : $0.13 \mathrm{nM}$ (permeability glycoprotein) ratio: 1.4 at $0.3 \mu \mathrm{M}$ ) [50]. It was paralleled by concepts with argininamide as central lead structure [65] [66]. Weiss et al. 2010 [65] and Keller 2015 [66] started from high affinity NPY1 receptor ligands-the guanidino compounds BIBO3304 [Figure 1, \{1\}] and BIBP 3226 [Figure $1\{2\}$ ) (Table 2), respectively, which already show sub-nanomolar affinity and appropriate log $\mathrm{P}$ and molecular weight.

Series of substitutions at the guanidino moieties supplied several further high affinity compounds.

However, already, the parent compounds had molecular weights of $500 \mathrm{kDa}$. Finally, the high affinity compounds, like $1 \mathrm{~m}$ (Figure $1\{3\}$ ) (Table 2) [65], compound 5 (Figure 1, $\{4\}$ ) instead of compound 5 (Figure 1, $\{5\}$ ) and Compound 23 [67] (Figure $1\{5\}$ ) instead of (Figure 1, \{4\}) (Table 2), suitable for labelling with C-11 or F-18 were in a range which no longer meets the requirements to molecular size proposed by Lipinski et al. [68] for a drug diffusible at the BBB.

A potential application for investigations of the spinal cord where the brain spinal cord barrier (BSCB) provides higher permeability in comparison to BBB [46] remains to be elucidated, especially, for conditions connected with inflammatory processes.

Recently, Kawamura et al. [69] presented ureido phenyl dihydroxypyridine dicarboxylates, which are available as $\left[{ }^{11} \mathrm{C}\right]$ BMS 193858, C-11-labelled in the 
ureido moiety (desmethylated compound) or at the methoxy cyclohexane moiety (methylated compound; Table 2) (Figure 1 [6]).<smiles>N=C(N)NCCC[C@H](NC(=O)C(c1ccccc1)c1ccccc1)C(=O)NCc1ccc(CNC(N)=O)cc1</smiles>

1<smiles>NCC(=O)NCc1ccc(O)cc1</smiles><smiles>CC(C)C(=O)NCCCNC(=O)CNC(N)NCCC[C@H](NC(=O)C(c1ccccc1)c1ccccc1)C(=O)NCc1ccc(O)cc1</smiles>

5<smiles>NC(N)NCCC[C@H](NC(=O)C(c1ccccc1)c1ccccc1)C(=O)NCc1ccc(O)cc1</smiles>

2<smiles>CCC(=O)NCc1ccc(CNC(=O)NCc2ccc(CNC(=O)[C@H](CCCNC(=N)N)NC(=O)C(c3ccccc3)c3ccccc3)cc2)cc1</smiles>

4<smiles>COC(=O)C1=C(C)NC(C)=C(C(=O)OC)C1c1cccc(NC(=O)NCCCN2CCC(C3=CCCC(OC)=C3)CC2)c1</smiles>

6

Figure 1. Small-molecule ligands at neuropeptide Y1 receptors:

1 (R)-2-(2,2-diphenylacetamido)-5-guanidino-N-(4-(ureidomethyl)benzyl)pentanamide; 2 (R)-5-((diaminomethyl)amino)-2-(2,2-diphenylacetamido)-N-(4-hydroxybenzyl)pentanamide; 3 (2R)-5-((amino(3-(4-(aminomethyl)-1H-1,2,3-triazol-1-yl)propanamido)methyl)amino)2-(2,2-diphenylacetamido)-N-(4-hydroxybenzyl)pentanamide; 4 (R)-2-(2,2-diphenylacetamido)5-guanidino-N-(4-((3-(4-(propionamidomethyl)benzyl)ureido)methyl)benzyl)pentanamide; 5 (2R)-2-(2,2-diphenylacetamido)-5-((E)-2-((4-(2-(fluoro- $\left.{ }^{18} \mathrm{~F}\right)$ propanamido)butyl)carbamoyl)gu anidino)-N-(4-hydroxybenzyl)pentanamide; 6 dimethyl 4 -(3-(3-(3-(4-(methoxy- $\left.{ }^{11} \mathrm{C}\right)$-piperidin-1-yl)propyl)ureido)phenyl)-2,6-dimethyl-1,4-dihydropyridine-3,5-dicarboxylate. ChemDraw (http://www.cambridgesoft.com/) was used for verification of IUPAC names. 
Table 2. Representative nonpeptide, small-molecule compounds of the four groups of Class A and Class B1 G-protein coupled receptor, as well as general mutual features in pharmacodynamics, pharmacokinetics and current progress in modelling (numbers in brackets behind the compound are related to the numbers of small-molecules in the respective figures).

\begin{tabular}{|c|c|c|c|c|c|c|}
\hline Receptors & GPCR Class & Compounds & References & General features & Modelling & References \\
\hline Neuropeptide Y1 & $\begin{array}{l}\text { Class A, } \\
\text { (peptide } \\
\text { receptor) }\end{array}$ & $\begin{array}{l}\text { Y-973 } \\
\text { BIBO3304 [1] } \\
\text { BIP3226 [2] } \\
\text { Cmpd. } 5[4] \\
\text { Cmpd. } 23[5] \\
\text { BMS } 193858[6]\end{array}$ & $\begin{array}{l}{[50]} \\
{[66]} \\
{[66]} \\
{[66]} \\
{[67]} \\
{[69]}\end{array}$ & $\begin{array}{l}\text { Selective } \\
\text { antagonists with } \\
\text { PK drawbacks like } \\
\text { high molecular } \\
\text { weight, high Pgp }\end{array}$ & $\begin{array}{l}\text { Complete crystal } \\
\text { structures of NPY } \\
\text { receptors yet not } \\
\text { available, but } \\
\text { interaction at }\end{array}$ & $\begin{array}{l}{[48]} \\
{[65][67]}\end{array}$ \\
\hline Neuropeptide Y2 & $\begin{array}{l}\text { Class A, } \\
\text { (peptide } \\
\text { receptor) }\end{array}$ & $\begin{array}{l}\text { BII246 } \\
\text { JNJ31020028 [7] } \\
\text { CYM9691 [8] } \\
\text { CYM9624 [9] }\end{array}$ & $\begin{array}{l}{[65]} \\
{[70]} \\
{[63]} \\
{[63]}\end{array}$ & $\begin{array}{l}\text { ratio or } \\
\text { inappropriate } \log \mathrm{P}\end{array}$ & $\begin{array}{l}\text { binding pocket of } \\
\text { NPY2R } \\
\text { investigated }\end{array}$ & \\
\hline Orexin-1 & $\begin{array}{l}\text { Class A } \\
\text { (peptide } \\
\text { receptor) }\end{array}$ & $\begin{array}{l}\text { SB334867 [13] } \\
\text { rac-10 [14] } \\
\text { Cmpds. } 47-51[15][16] \\
\text { Cmpd. } 54[17] \\
\text { Cmps. } 24[18] \\
\text { SB674042 [21] }\end{array}$ & $\begin{array}{l}{[89][90]} \\
{[91]} \\
{[91]} \\
{[79]} \\
{[92]} \\
{[94]}\end{array}$ & $\begin{array}{l}\text { Selective } \\
\text { antagonists with } \\
\text { PK drawbacks like } \\
\text { high molecular } \\
\text { weight, high Pgp }\end{array}$ & $\begin{array}{l}\text { Complete crystal } \\
\text { structure available }\end{array}$ & 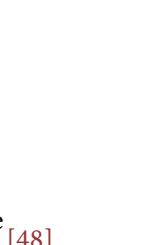 \\
\hline Orexin-2 & $\begin{array}{l}\text { Class A } \\
\text { (peptide } \\
\text { receptor) }\end{array}$ & $\begin{array}{l}\text { 2-SORA-DMP [22] } \\
\text { TCSOX229 [23] } \\
\text { Cmpd [24] } \\
\text { Cmpd. } 4 \text { f [25] } \\
\text { Diazaspiro-cmpds. [26] [27] [28] } \\
\text { CW4 [30] }\end{array}$ & $\begin{array}{l}{[94]} \\
{[95]} \\
{[96][97]} \\
{[97]} \\
{[98]} \\
{[99]}\end{array}$ & $\begin{array}{l}\text { ratio or } \\
\text { inappropriate log } \\
\text { P; low density of } \\
\text { the receptors in } \\
\text { brain tissue }\end{array}$ & $\begin{array}{l}\text { for both receptor } \\
\text { subtypes }\end{array}$ & \\
\hline $\begin{array}{l}\text { CX3CR1 } \\
\text { (Fractalkine receptor) }\end{array}$ & $\begin{array}{l}\text { Class A } \\
\text { (chemokine } \\
\text { receptor) }\end{array}$ & $\begin{array}{l}\text { AZD8797 [37] } \\
\text { FBTTP [41] }\end{array}$ & $\begin{array}{l}{[42]} \\
{[49]}\end{array}$ & $\begin{array}{l}\text { Functional } \\
\text { antagonist with } \\
\text { high log P and } \\
\text { good p.o. efficacy }\end{array}$ & $\begin{array}{l}\text { Modelling with } \\
\text { US28; Fractalkine } \\
\text { characterized; } \\
\text { crystal structure } \\
\text { of the receptor } \\
\text { incomplete }\end{array}$ & [48] \\
\hline $\begin{array}{l}\text { Corticotropin releasing } \\
\text { factor }\end{array}$ & $\begin{array}{l}\text { Class B1 } \\
\text { (peptide } \\
\text { receptor) }\end{array}$ & $\begin{array}{l}\text { CP316311 } \\
\text { CP376395 [42] } \\
\text { BMS6650553 [52] } \\
\text { Phenylaminopyrazinones [44] [45] } \\
\text { [46] } \\
\text { Dihydropyridinpyrazonones [47] } \\
{[48][49][50][51]}\end{array}$ & $\begin{array}{l}{[119]} \\
{[59]} \\
{[122][123]} \\
{[120]} \\
{[121]}\end{array}$ & $\begin{array}{l}\text { Rather allosteric } \\
\text { binding and } \\
\text { pharmacokinetic } \\
\text { drawbacks }\end{array}$ & $\begin{array}{l}\text { Complete CRFR1 } \\
\text { crystal structure } \\
\text { available; first } \\
\text { studies with } \\
\text { CP376395 }\end{array}$ & $\begin{array}{l}{[48]} \\
{[59]} \\
{[60]}\end{array}$ \\
\hline
\end{tabular}

The authors investigated in first in vivo experiments the distribution of the compounds in mice with Elacridar-an inhibitor of permeability glycoprotein (Pgp) and of breast cancer resistance protein (BCRP). The methylated BMS 193858 showed better uptake into the brain. Elacridar increased the uptake of the test substance in lung, heart, muscle and brain although the total accumulation in the brain stood below $1 \%$ of the injected dose during the observation period. Uptake of the desmethylated compound was increased only in the liver and the heart [69].

Regarding binding-site structure and density-related PET, NPY2 receptors are found in the brain with high incidence. However, functional approach has to 
take in account that NPY2 binding sites are also presynaptic receptors providing by this way a more complex response on potential therapeutics. Simultaneously, this requires more differentiated approaches to interpretation of changes in density.

A first real breakthrough with relevance for availability of a NPY2 receptor PET tool was the study by Winterdahl et al. in 2014 [70] concerning radiosynthesis of N-[ $\left[{ }^{11} \mathrm{C}\right]$ methyl-JNJ31020028 (Figure 2, $\{7\}$ ) (Table 2). The tracer had been proposed 2010 by Shoblock et al. [71] (Johnson \& Johnson Pharmaceutics) and submitted to first tests in Sprague daily rats. Later, Mitapalli \& Roberts (2014) [72], modified lead structures proposed, originally, by GlaxoSmithKline group around Lunniss et al. 2009 [73].<smiles></smiles>

7<smiles>CN(C)S(=O)(=O)c1ccc(NC(=S)N2CCC([C@](O)(c3ccccc3)c3ccccn3)CC2)cc1</smiles>

8<smiles>CCN(CC)C(=O)C(c1ccccc1)N1CCN(c2ccc(NC(=O)c3c(C)noc3C)cc2F)CC1</smiles>

10<smiles>CCN(CC)C(=O)C(c1ccccc1)N1CCN(c2ccc(NC(=O)C3(c4ccccc4)CCCC3)cc2F)CC1</smiles>

11

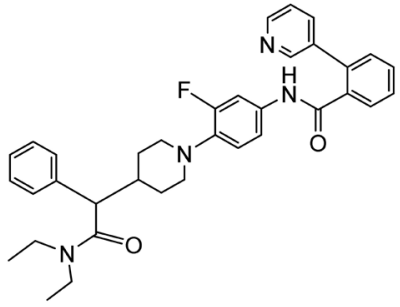

12

Figure 2. Small-molecule ligands at neuropeptide Y2 receptors:

$7 \mathrm{~N}$-(4-(4-(2-(diethylamino)-2-oxo-1-phenylethyl)piperazin-1-yl)-3-fluoro-phenyl)-N-(methyl-11C)-2-(pyridin-3-yl)benzamide; $8 \mathrm{~N}$-(4-(N,N-dimethylsulfamoyl)phenyl)-4-(hydroxy(phenyl)(pyridin-2-yl)methyl)piperidine-1-carbothioamide; $9 \mathrm{~N}$-(4-(N,N-dimethylsulfamoyl)phenyl)-4-(6-oxo-6,11-dihydro-5H-dibenzo[b,e]aze-pin-11-yl)piperazine-1-carbothioamide; $10 \mathrm{~N}$-(4-(4-(2-(diethylamino)-2-oxo-1-phenylethyl)piperazin-1-yl)-3-(fluoro- $\left.{ }^{18} \mathrm{~F}\right)$ phenyl)-3,5-dimethylisoxazole-4-carboxamide; $11 \mathrm{~N}$-(4-(4-(2-(diethylamino)-2oxo-1-phenylethyl)piperazin-1-yl)-3-fluorophenyl)-1-phenylcyclopentane-1-carboxamide; 12 N-(4-(4-(2-(diethyl-amino)-2-oxo-1-phenylethyl)piperidin-1-yl)-3-fluorophenyl)-2(pyridine-3-yl)benzamide. 
Winterdahl and colleagues [70] tested the ${ }^{11} \mathrm{C}$-labelled methylated analogue (Figure 2, \{7\}) first time in pigs. Earlier developed NPY2 ligands, e.g. BIIE246, could not be transferred in brain PET clinical imaging also due to a too high molecular weight resulting in pseudo-peptidic properties and, finally, in abolishment of the diffusion through the $\mathrm{BBB}$. The $\mathrm{IC}_{50}$ of $3.3 \mathrm{nM}$ in competitive binding assays with $\left[{ }^{125} \mathrm{I}\right]$ NPY corresponded at least to a moderate affinity beyond the sub-nanomolar scope [72]. Finally, the description by Dautzenberg et al. [74] (Johnson \&Johnson Research and Development, Hofmann la Roche.) as an irreversibly binding, unsurmountable ligand prevented BIE246 as a potential brainPET tracer.

BIIE246 and further derivatives (CYM9691 and CYM9624) (Figure 2, $\{8\}\{9\}$ ) (Table 2), however, were useful in testing structural interactions with a comparative molecular model of the NPY2 receptor [63] [75]. In difference to orexin receptors or CRFR1 there is yet not complete crystal structure of NPY receptors. Site-directed mutagenesis, especially with alanine, allowed identification of functionally important amino acids of NPY receptors in a comparative structure model. Gl135, Leu 284 and, particularly, Leu227 in the TMD5 of the NPY2 receptor were recognized as crucially important for the interaction with the endogenous ligands.

For NPY1, four amino acids in ECD1 and ECD2 as well as in TMD7 were identified as potentially important for binding of endogenous ligands [63].

Mitapalli \& Roberts from Scripps laboratories modellized in several series and different core structures anilide derivatives with moderate affinities (compound 57; Figure 2, $\{10\}$ ) and 63 (Figure $2\{11\}$ ) and, finally, was disclosed compound 83 , with appropriate affinity of $7 \mathrm{nM}$ (Figure $2\{12\}$ ).

For NPY1 receptors the problem of selectivity, especially versus NPY4 receptors, belongs to the questions to be asked also in molecular modelling models. Resolving this will define and complete not only preliminary pharmacophore models but also important differences in the action of endogenous ligands and differences between diverse GPCR classes [76].

\section{Orexin Receptors}

Orexin receptors have been suggested to play special roles in neuroprotection (OX1R), wake sleep-cycle, pro-arousal effects and feeding behavior (OX2R) [77] [78]. A well-known role of OX2R had been demonstrated already early for the pathogenesis of narcolepsy [79] [80]. This finding triggered the idea to develop not only drugs promoting wakefulness against narcolepsy but also drugs for treatment of insomnia. The prevalence of insomnia has been estimated in European countries with $6 \%(5 \%-11 \%)$, recently [57], independently of a deeper analysis including co-morbidities or drug addiction. The spectrum of hypnotics available for clinical use is broad but also hampered by diverse side effects [56] [57] [81] [82] [83]. Recently, also circadian periodicity of appetite and feeding behavior as well as hypothalamically mediated autonomic reactions linked with 
prodroma of migraine attacks move into the focus of migraine research. Orexins have been shown to influence hypothalamic reactions and activation of the trigeminal cervical complex (TCC) [84]. Orexin A is reported to inhibit activation of the TCC, while Orexin B, 10 fold more active at the OX2R than at OX1R, is supposed to activate the TCC as well as premonitory autonomic symptoms of the migraine attack. Dysregulations of the orexin system resulting in higher orexin concentration in the cerebrovascular liquor of patients are suggested to be involved in occurrence of depressive periods in humans [85].

Signal transmission has been described for OX1R, predominantly, mediated by $\mathrm{G}_{\mathrm{q}}$ protein and $\mathrm{OX} 2 \mathrm{R}$ via $\mathrm{G}_{\mathrm{s}}$ and $\mathrm{G}_{\mathrm{q}}$ or $\mathrm{G}_{\mathrm{i}}$. In vitro $\mathrm{OX} 1 \mathrm{R}$ and $\mathrm{OX} 2 \mathrm{R}$ are able to formation of dimeres and able of induction of $G_{q}, G_{s}$ or $G_{i}$ protein signaling [85]. Potentially, this can induce also diverse functional interferences between these and other receptors in vivo.

First approved orexin receptor antagonist with dual affinity to OX1R and OX2R (DORA: dual orexin receptor antagonists) was disclosed 2014 with suvorexant. Its analogue almorexant had been confirmed to remain without improvement of wakefulness in OX2R knock-out mice [86] [87], although some effect on REM (rapid eye movement) sleep was observed [87]. Compared to the hypnotics commonly used clinically, the approach via ligands of orexin receptors is relatively new in the field of hypnotics and the idea of involvement in therapy of migraine even newer. While potential therapeutics, hitherto, predominantly are dual orexin receptor ligands like suvorexant, also more and more scaffolds of selective OXR antagonists (SORA) are published. The OX1R is the receptor type described to be expressed by a larger extent in pathological conditions especially, following traumatic injury also due to its presence in microglia cells and migration of microglia into foci of injured tissue [19].

First OX1R antagonist was SB 334867 [88] [89] [90] (Figure 3, \{13\}) (Table 2 ). However, the selectivity was at least rather limited because the compound showed interactions also with some receptors of the amine cluster as well as with purine receptors [88].

Roecker et al. reviewed in 2016 (Merck) [79] fifty patents submitted alone in the time between 1999 and 2007 based on the orexin receptor approach. Recently, the Merck-working group of Stump et al. [91] modified a lead structure with ether-linked aromatic ring and piperidine core scaffold revealing diverse characteristic influences of substitutions. Finally, high affinity compounds were recommended by Stump et al. [91] as potential lead structures for the development of therapeutics. The start was the OX1R compound rac-10 (Figure 3, $\{14\}$ ) (Table 2) and, finally, obtaining related compounds 47 and 51 (Figure $3,\{15\}$ \{16\}) (Table 2) with appropriate affinities at hOX1R (5.2 and $1.8 \mathrm{nM} \mathrm{K}_{\mathrm{i}}$, respectively). A difluoropiperidine core linked with 2 hydroxyquinoline was identified as key structure with influence on the selectivity for OX1R or OX2R [91]. Easy transformations of OX1R into OX2R preferring ligands were demonstrated. 
<smiles>CC1Nc2ccc(NC(=O)Nc3ccnc4cccnc34)cc2O1</smiles>

13<smiles>O=C(c1ccccc1-n1nccn1)N1CCC(F)(F)C(Oc2cnc3ccccc3c2)C1</smiles>

14<smiles>O=C(c1nccc2[nH]cnc12)N1CCC(F)(F)C(Oc2ccc3ccccc3n2)C1</smiles>

15<smiles>O=C(c1cccn2ccnc12)N1CCC(F)(F)C(Oc2ccc3ccccc3n2)C1</smiles>

16<smiles>Cc1ccc(-n2nccn2)c(C(=O)N2CCC(F)(F)C(Oc3ccc4ccccc4n3)C2)c1</smiles>

17<smiles>CCN(C(=O)c1cc(F)ccc1-c1ncccn1)C(C)Cn1nnc(-c2ccc(F)cc2)n1</smiles>

18<smiles></smiles>

19<smiles>COc1c(F)cccc1C(=O)N1CC(C)CCC1CNc1ccc(Br)cn1</smiles>

20<smiles>Cc1nc(C(=O)N2CCC[C@H]2Cc2nnc(-c3ccccc3)o2)c(-c2ccccc2F)s1</smiles>

21

Figure 3. Small-molecule ligands at orexin-1-receptors:

13 1-(2-methyl-2,3-dihydrobenzo[d] oxazol-6-yl)-3-(1,5-naphthyridin-4-yl)urea; 14 (2-(2H1,2,3-triazol-2-yl)phenyl)(4,4-difluoro-3-(quinolin-3-yloxy)piperidin-1-yl)methanone; 15 (4,4-difluoro-3-(quinolin-2-yloxy)piperidin-1-yl)(1H-imidazo[4,5-c]pyridin-4-yl)methanone; 16 (4,4-difluoro-3-(quinolin-2-yloxy)piperidin-1-yl)(imidazo[1,2-a]pyridin-8-yl)methanone; 17 (S)-(2-(2H-1,2,3-triazol-2-yl)phenyl)(4,4-difluoro-3-(quinolin-2-yloxy)piperidin-1-yl)methanone; 18 (S)-N-ethyl-5-fluoro-N-(1-(5-(4-(fluoro- $\left.{ }^{18} \mathrm{~F}\right)$ phenyl)-2H-tetrazol-2-yl)propan-2-yl)-2-(pyrimidin-2-yl)benzamide; 19 (E)-N-((4R,7R,7aR,12bS)-3-((2-(dimethylamino)phenyl)sulfonyl)-4a-hydroxy-9-methoxy-2,3,4,4a,5,6,7,7a-octahydro-1H-4,12-methanob enzofuro[3,2-e] isoquinolin-7-yl)-N-methyl-3-(pyridin-2-yl)acrylamide; 20 5((2S,5S)-2-(((5bromopyridin-2-yl)amino)methyl)-5-methylpiperidin-1-yl)(3-(fluoro- $\left.{ }^{18} \mathrm{~F}\right)-2$-methoxyphenyl)methanone; 21 (S)-(5-(2-(fluoro- $\left.{ }^{18} \mathrm{~F}\right)$ phenyl)-2-methylthiazol-4-yl)(2-((5-phenyl-1,3,4oxadiazol-2-yl)methyl)pyrrolidin-1-yl)methanone. 
Also Roecker et al. [79] described easy transitions from dual orexin antagonists to OX1R inhibitors and OX2R inhibitors presenting cmpd 54 as OX1R inhibitor [Figure 3, \{17\}) (Table 2). The authors proposed a pharmacophore model of physicochemical properties together with investigations of pharmacokinetic behavior of selective OX1R and OX2R antagonists and DORA as well as possibilities of cyclization and adduct formation of metabolized compounds.

Futamura et al. [92] proposed a further OX1R ligand together with first molecular modelling results of related derivatives. Compound 24, a pyrazoylethylbenzamide (Figure 3, \{18\}) (Table 2), showed an appropriate $\mathrm{K}_{\mathrm{i}}$ value of $2.1 \mathrm{nM}$ and 265 fold selectivity over OX2R. The authors [92] suggested the development of OX1R antagonist as therapeutics influencing behavior in stress and anxiety without inducing somnolence. Finally, such drugs, if they are effective, would require very differentiated decisions on their application. Apart from that, for a potential use in the diagnostics of such processes, remains the question of sufficiently high $\mathrm{B}_{\max }$ values in the brain areas of interest which have to be targeted by such a tracer.

Nagase et al. [93] synthesized a compound (cmpd. 71, $\mathrm{K}_{\mathrm{i}} 1.36 \mathrm{nM}$ ) (Figure 3, \{19\}) with a morphinan structure and a molecular weight somewhat about the 500 Da-border proposed by Lipinski et al. for free diffusible drugs entering the brain. The authors compared compound 71 in modelling experiments with suvorexant and other small molecules.

The ligands, in the focus of the study by Yin et al. [94], were the selective OX1R antagonist SB674042 (Figure 3, \{21\}), the selective OX2R antagonist 2-SORA-DMP (Figure 4, \{22\}) (Table 2) [94] as well as a dual-selective analog of suvorexant, DORA-12. In general also for OX2R diverse antagonists of appropriate affinity have been found, which, however, did not achieve sub-nanomolar range of affinity. First of these compounds, TCSOX229, was published by Hirose et al. [95] 2003 (Figure 4, \{23\}).

Starting from a lead structure developed by the group of Mensch et al. [96] (Merck) (Figure 4, \{24\}) (Table 2). Fujimoto et al. (Takeda) [97] provided in 2011 a series of spiro compounds with a first antagonist selective to OX2R, developed originally for oral application. However, the sulfonyl fluoro diazaspiro carboxamide $4 \mathrm{f}$ [Figure $4,\{25\}$ ) (Table 2) characterized with an $\mathrm{IC}_{50}$ of $3.3 \mathrm{nM}$, a $\log \mathrm{P}$ of 3.9 (ACD/ChemSketch) and a $\log \mathrm{D}$ of 1.35 could be also a lead structure of ligands for PET analysis.

Further successful efforts were presented by Betschart et al. [98] (Novartis) which reported a series of diazaspiro-compounds with SORA OX2R (Figure 4, $\{26\}\{27\}\{28\}$ ) (Table 2) and DORA antagonistic properties and tested these in mouse models.

EEG investigations revealed that selective OX2R antagonists could improve only non-REM-sleep but dual OXR antagonist improved also REM sleep. For a potential application in PET imaging, some of the OX2R selective antagonists with appropriate $\log \mathrm{P}, \mathrm{K}_{\mathrm{i}}$ values and $\mathrm{MW}$ appeared better suitable than the 
recommended, orally effective, compound 26 (Figure 4, \{26\}) with $\mathrm{pK}_{\mathrm{i}}$ of 7.85 and $\log \mathrm{P}$ of 4.9 , even if there are yet no in vivo data available. This remains to confirm at least for the compounds 30 (Figure $4,\{27\}$ ) with $\mathrm{pK}_{\mathrm{i}} 9.78$ but $\log \mathrm{P}$ of 5.0 and compound 35 (Figure 4, \{28\}) with $\mathrm{pK}_{\mathrm{i}}$ of 8.73 and $\log \mathrm{P}$ of 3 [98] showing higher affinity.<smiles>Cc1cc(N2CC[C@@H](C)N(C(=O)c3ccccc3-n3nccn3)CC2)nc(C)n1</smiles>

22<smiles>O=S(=O)(c1ccccc1)N1CCCC12CCN(c1cnc3ccccc3n1)CC2</smiles>

24<smiles>COc1ccnc(N2CCC3(CCCN(Cc4c[nH]c5ccccc45)C3=O)CC2)n1</smiles>

26<smiles>COc1cc2c(cc1OC)CN(C(=O)C(NCc1ccncc1)C(C)(C)C)CC2</smiles>

23<smiles>COc1ccc(S(=O)(=O)N2CCOC23CCN(C(=O)Nc2ccccc2)C[C@@H]3F)cc1OC</smiles>

25<smiles>COc1ccc2[nH]cc(CN3CCCC4(CCN(c5nc(C)cc(C)n5)CC4)C3=O)c2c1</smiles>

27<smiles>Cc1cc(C)nc(N2CCC3(CCCN(Cc4n[nH]nc4-c4ccccc4)C3=O)CC2)n1</smiles>

28

Figure 4. Small-molecule ligands at orexin-2-receptor:

22 (R)-(2-(2H-1,2,3-triazol-2-yl)phenyl)(4-(2,6-dimethylpyrimidin-4-yl)-7-methyl-1,4diazepan-1-yl)methanone; 23 (2S)-1-(3,4-Dihydro-6,7-dimethoxy-2(1H)-isoquinolinyl)3,3-dimethyl-2-[(4-pyridinylmethyl)amino]-1-butanone; 24 1-(phenylsulfonyl)-8-(quinoxalin-2-yl)-1,8-diazaspiro[4.5]decane; 25 (5S,6S)-4-(3,4-dimethoxyphenyl)sulfonyl)-6fluoro-N-phenyl-1-oxa-4,8-diazaspiro[4.5]decane-8-carboxamide; 26 2-((1H-indol-3-yl)methyl)-9-(4-methoxypyrimidin-2-yl)-2,9-diazaspiro[5.5] undecan-1-one; 27 9-(4,6-Dimethylpyrimidine-2-yl)-2-((5-methoxy-1H-indol-3-yl)methyl)-2,9-diazaspiro[5.5] undecan-1-one; 28 9-(4,6-Dimethylpyrimidin-2-yl)-2-((5-phenyl-2H-1,2,3-triazol-4-yl)methyl)2,9-diazaspiro [5.5] undecan-1-one. 
Wang et al. [99] described a diazepane analogue of suvorexant with high selectivity for OX2R (Figure 5, $\{30\}$ ).

With experimental data obtained 2009 by Malherbe et al. [100] for the SORA-2 antagonist EMPA, the authors required the binding potential (BP) as the product of $B_{\max }$ and affinity $\left(1 / k_{d}\right.$ or $\left.1 / K_{i}\right)$ has to provide minimal the value 10 . With $\mathrm{B}_{\max }$ of $40-140 \mathrm{fmol} / \mathrm{mg}$ protein determined using EMPA $\left(\mathrm{K}_{\mathrm{i}} 1.1 \mathrm{nM}\right)$ in autoradiography of coronal rat brain sections and with the prerequisite that fmol/mg protein was corresponding to $\mathrm{nM}$ concentrations, the authors concluded that a $\mathrm{BP}$ between 3 and 30 could be achieved. This would be so far possible also in vi$v o$ if there is no pharmacokinetic obstacle and the complete dose penetrates the BBB or BSCB even if the water content of brain tissue with 70 and $85 \%$ would be taken into account [101] [102] [103] [104] [105].<smiles>COCc1nc(C)ncc1OCC1(c2cccc(F)c2)CC1C(=O)Nc1ccc(F)cn1</smiles>

29<smiles>CC1CCC(Oc2cc(C#N)ccn2)CN1C(=O)c1ccccc1-n1nccn1</smiles>

31<smiles>Cc1ccc(-n2nccn2)c(C(=O)N2CC(Oc3ccnc4c(F)cccc34)CC[C@H]2C)c1</smiles><smiles>COc1ccccc1C(=O)N1CCCN(c2nc3ccc(Cl)cc3s2)CC1</smiles>

30<smiles>CC1CCC(Oc2nccc3c2C(=O)OC3(C)C)CN1C(=O)c1ccccc1-n1nccn1</smiles>

32

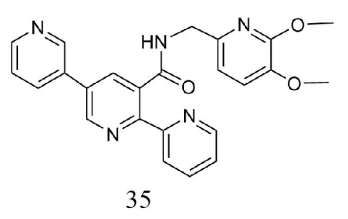

Figure 5. Small-molecule ligands at orexin 2 receptors:

29 (1R, 2-(3 N-(5 fluoropyridin 2 2-((4-(2 methylpyrimidin-5-yl)oxy)methyl)cyclopropane 1 carboxamide; 30 (4-(6-chlorobenzo[d]thiazol 2 1,4 diazepan-1 yl)(2-(methoxy $\left.{ }^{11} \mathrm{C}\right)$ phenyl)methanone; 31 2-(((1-(2-(2H 1,2,3 triazol-2yl)-6-methylpiperidin-3-yl)oxy)isonicotinonitrile; 32 4-(( $3 \mathrm{R}, 1-(2-(2 \mathrm{H} 1,2,3$ triazol 2 yl)-6-methylpiperidin $3 \mathrm{yl}) 1,1$ dimethylfuro[3,4c]pyridine-3-(one; 33 (2-(2H 1,2,3 triazol-2 yl)phenyl) $((2 \mathrm{R}, 5-((8$ fluoroquinolin 4 yl) 2 methylpiperidin-1-yl) methanone; 34 (5-(4,6 dimethylpyrimidin-2 yl)hexahydropyrrolo[3,4 c]pyrrol-2(yl)(2-(fluoro-6-(2H-1,2,3triazol-2-yl)phenyl)methanone; $35 \mathrm{~N}$ ((5,6 dimethoxypyridin 2 yl)methyl)-[2,2':5',-3-terpyridine] 3'-carboxamide. 
At least, however, an affinity of the tracers in sub-nanomolar range would be preferable even if physicochemical properties can be optimal. Indeed, Wang et al. [99] showed binding to different brain areas with the $\left[{ }^{11} \mathrm{C}\right]$ labelled compound CW4 (Figure 5, \{30\}) (Table 2) in the brain of baboons [99]. Contributions of microglia and neurons had not been discriminated during these experiments.

Recently, Skudlarek et al. [106] described several series of potential drug candidates with more or less suitable pharmacokinetic properties and receptor affinities (Figure 5, $\{31\}\{32\}\{33\}$ ). Although the general content and motivation remains the treatment of insomnia with antagonists of OX2R, the group provides many suggestions to pharmacophore development of ligands not only for OX2R but also for OX1R. A comparison of ligand binding mechanisms was performed at an engineered receptor construct using the third intracellular loop of the hOX1R [94].

A series of cyclo propane carboxamide structures published 2013 by Oi et al. [107] showed with inverse frequency rather a role as Pgp substrate and increased lipophilic features. One compound (9a) (Figure 5, \{29\}) with $\log$ P of 3.29 and $\log$ D 2.97 was shown with appropriate binding in the brain of a Pgp knock-out rat.

A Pgp flux ratio of 3.11, in the border range of appropriate values, avoids a use without support of Pgp inhibitors.

Related structures were proposed by Gao et al. [108] as OX2R antagonists. Roecker et al. [79] developed the isoquinoline compound 53 as a candidate for labelling with a positron emitter (Figure 5, $\{34\}$ ). With a suitable $\log \mathrm{P}$ and high affinity binding it could acquire also sufficient properties as a PET tracer.

\section{CX3CR1 (Fractalkine Receptor)}

During the last five years more and more attention has been paid to a special role of microglia and its CX3C (chemokine CX3C) receptor 1 subtype (fraktalkine receptor) in induction of obesity and the immunological response mediated by this receptor under conditions of high fat diet [109] as well as sex differences in the CX3CL-CX3CR signaling of CX3CR1 knock-in mice [110]. The receptor is suggested to be responsible for the enhanced sensitivity of male animals associated with high fat diet. Although quantitative data on the expression of receptor protein in microglia membranes are not available, approaches have been done earlier, in 1998 by Nishiyori et al. [17], with mRNA in situ hybridization studies in rat brain (Table 1). The results showed high levels of receptor mRNA in microglia cells compared to neurons and astrocytes while fractalkine mRNA was very high in neurons in comparison to astrocytes and microglia [17]. The receptor has been reported, meanwhile, with tenfold increased density in microglia compared to macrophages, neurons or astrocytes [16] [17]. In the periphery, CX3CR1-expressing monocytes have been demonstrated as immune surveillant of blood vessels. Such cells were able to invade into the tissue if irritants were present [111]. Determination of small RNAs for specific signature proteins allows the differentiation between glia subtypes of different stages of development 
or diseases, at subcellular level [6].

CX3CR1 plays not a critical role for short-term survival, but was demonstrated to show enhanced expression on microglia associated with injuries of CNS and spinal cord [53] [54]. Microglia and monocyte-derived macrophages promote in spinal cord lesions inflammatory responses. Freria et al. [53] demonstrated in CX3CR1-/-mice that the deficiency of CX3CR1 interrupts pro-inflammatory signal chains of these cells and support repair and sprouting processes in neuronal synapses. Earlier, the soluble and the membrane-anchored forms of $\mathrm{CX} 3 \mathrm{CL}$ - the endogenous ligand of the receptor, had been described. The knock-out of CX3CR1 resulted in decrease of atherogenesis but also enhancement of inflammation in the brain and development of pain as well as age related macular degeneration [112] [113].

The membrane-anchored CX3CL1 (fractalkine) contributes to binding of leukocytes expressing CX3CR1 without involvement of adhesion proteins or integrines in the periphery. This suggests therapeutic potential of CX3CR1 inhibition after spinal injury. Whether in vivo imaging would can supply information on healing processes using PET remains to be elucidated.

First trials for the development of CX3CR1 antagonists were focused on chemokine analogues usually characterized by molecular weights between 8 and 10 $\mathrm{kDa}$ [112] [113].

To date, the number of potentially effective small molecules available for labeling of CX3CR1 is very limited [42] [43] [51].

Karlström et al. [42] and Cederblad et al. [43] described AZD8797 (Figure 6, \{37\}) (Table 2) as a first orally applicable drug. Starting from previously used small molecules known to interact with chemokine receptors Karlström et al. choose two 7-[amino-5-thio-thiazolo-[4,5-d]pyrimidine core structures and modified substituents of the two side chains (Figure $6\{36\}\{37\}\{38\}\{39\}\{40\}$ ) (Table 2). Two series of compounds were developed including neutral amino thiazolopyrimidines (series A) and acidic thiazolopyrimidinones (series B) which were further tested also for their selectivity for CX3CR1. Generally, membrane permeability was higher for series B compounds. However, for compound 18a (AZD8797; series A) was found appropriate selectivity for CX3CR1 in comparison to some other chemokine receptors, but also a more intensive interaction with adenosine $A 1$ receptors $\left(K_{i}\right.$ of $\left.132 \mathrm{nM}\right)$ and a 33 fold selectivity. Selectivity versus receptors of the amine cluster was 200 fold for CX3CR1 [42]. AZD8797 revealed in comparative experiments with fractalkine its binding site separate from that of the endogenous ligand. It is an allosteric ligand with noncompetitive binding at the receptor [42] [43].

Its analogue $\left[{ }^{18}\right.$ F] FBTTP [Figure $6\{41\}$ ) (Table 2) was 2015 disclosed by Mease et al. [49] as potential PET tracer of the CX3CR1. Further information on results of PET investigations is, however, yet not available.

In difference to the Class A orexin receptor and also to Class B1 CRF1 receptor, the crystal structure of CX3CR1 is yet not available, completely. To date, a structural model of CX3CR1 for molecular dynamics studies is employed based 
on the US28 structure (cytomegalovirus-encoded chemokine receptor homologue), however currently, with limited power of the deduced conclusions.

Also the crystal structure of adenosine A1 receptors is in progress [114], but not yet complete, what hampers the discrimination of structural features of the receptors responsible for the deficit in selectivity small-molecule ligands of CX3CR1.

Some investigations with AZD8797 as drug in animal disease models are promising. Ridderstad-Wollberg et al. [115] observed in a first therapeutic experiment in Agouti mice suffering from EAE (experimental autoimmune encephalitis) a common model of multiple sclerosis, effective action of the drug if applied before start of the disease [115].<smiles>CCC(CO)Nc1nc(SCc2ccccc2)nc2nc(N)sc12</smiles>

36<smiles>CCC(CO)Nc1nc(SCc2ccccc2)nc2[nH]c(=O)sc12</smiles>

38<smiles>CC(C)CC(CO)Nc1nc(SC(C)c2ccccc2)nc2nc(N)sc12</smiles>

40<smiles>CCCC(CO)Nc1nc(SCc2ccccc2)nc2nc(N)sc12</smiles>

37<smiles>CCCC(CO)Nc1nc(SCc2ccccc2)nc2[nH]c(=O)sc12</smiles>

39<smiles>CC(C)CC(CO)Nc1nc(SCc2ccccc2F)nc2nc(N)sc12</smiles>

41

Figure 6. Small-molecule ligands at CX3CR1:

36 2-((2-amino-5-(benzylthio)thiazolo[4,5-d]pyrimidin-7-yl)amino)butan-1-ol; 37 2-(2amino-5-(benzylthio)thiazolo[4,5-d]pyrimidin-7-yl)amino)pentan-1-ol; 38 5-(benzylthio)-7-((1-hydroxybutan-2-yl)amino)thiazolo[4,5-d]pyrimidin-2(3H)-one; 39 5-(benzylthio)-7-((1-hydroxypentan-2-yl)amino)thiazolo[4,5-d]pyrimidin-2(3H)-one; $40 \quad 2$-((2amino-5-((1-phenylethyl)thio)thiazolo[4,5-d]pyrimidin-7-yl)amino)-4-methylpentan-1-ol; 41 2-((2-amino-5-((2-(fluoro- $\left.{ }^{18} \mathrm{~F}\right)$ benzyl)thio)thiazolo[4,5-d]pyrimidin-7-yl)amino)-4methylpentan-1-ol. 


\section{CRF-Receptor-1}

CRFR and its endogenous ligands play a central role in the hypothalamic-pituitary-axis but are located and acting also widespread in the body. The CRF1 subtype of the corticotropin releasing factor receptor is most frequently target of drugs for therapeutic purposes and expressed by larger extent than CRF2 subtype. Diverse concepts had been developed for the involvement of the CRF1 receptor in the treatment of anxiety, depression, stress and posttraumatic disturbances. Some of the drugs proposed for such purposes had been labelled also with positron emitting isotopes, i.s. $\left[{ }^{11} \mathrm{C}\right] \mathrm{R} 121919,\left[{ }^{11} \mathrm{C}\right] \mathrm{SN} 003,\left[{ }^{76} \mathrm{Br}\right] \mathrm{MJL}-1-109-2$, $\left[{ }^{76} \mathrm{Br}\right] \mathrm{CP} 154,526$, too, but tested in primates with limited success [58]. In difference to NPY and orexin receptors, CRFR1, VIP and PTH receptors, belong to the Class B1 receptors of GPCR which are equipped with larger N-terminal domain than Class A receptors in, the range of 120 - 160 a.a.r., and binding sites for the C-terminus of the endogenous 40 and 41 mer peptide ligands. Simultaneously, the N-terminus of the endogenous ligands finds binding sites at the transmembrane domains [116].

The general expectations to the role of corticotropin releasing factor receptor ligands in future therapies of mental diseases returned to reality of structural constraints for these receptors, during the last years [117]. Simultaneously, a crucial role of CRF receptors in stress response and contributions to protection against stress remained beyond doubt. Spierling and Zorilla resumed 2017 [118] on the general behavioral approach to treat affective and anxiety diseases rather a lack of success and account that outcome, especially, to problems in physicochemical properties, use of different preclinical screening models and respective restriction of positive results only to certain animal models. Several therapeutic studies were stopped because of absence of efficacy of the treatment, e.g. was stopped already 2008 because of absence of efficacy in treatment of depression with pexacerfont and recently, a study with CP316311 [119] [120].

Not only clinical expectations but also trials to create orthosteric, reversible inhibitors of CRF1 receptors disappointed and rose questions on structural behavior of small molecules at that special class of receptors. The crystal structure of CFR1 receptor has been established as one of the first in the Class B1 of GPCRs [48] [59] [60] [61]. CRF1 receptor is regarded, hitherto, as the prototype of Class B GPCR used in molecular modelling studies for structure-activity investigations. While for fundamental understanding of the role of the receptor the interaction of the endogenous peptide ligands is of pivotal interest, for development of probes able to visualize pathologies of the brain with PET methods, interaction with small molecules is of high relevance.

There are only few studies using molecular dynamics for the proof of mechanism in this field. Bai et al. [60] and Hollenstein et al. [59] described 2013 and 2014 a first simulation of CRFR1 binding at the TMDs of the receptor with the allosteric antagonist CP376395 (Figure 7 \{42\}). Doré et al. [61] and Seidel et al. [116] published first studies with attention to the complete receptor structure 
[116]. While Seidel et al. were concerned with the interaction of CRFR1 receptor with peptide agonists and antagonists, Doré et al. focussed on small-moleculebinding sites. An interesting observation published by Seidel et al. was the functional transformation of peptide ligands applied as truncated derivatives of the endogenous ligands. The removal of the first 8 to 10 a.a.r. resulted in the transformation of agonists to partial antagonist and finally to full antagonists. Moreover, Seidel et al. identified binding sites for endogenous peptides at ECD (extracellular domains) and TMP (transmembrane domains) [116].<smiles>CCC(CC)Nc1cc(C)nc(Oc2c(C)cc(C)cc2C)c1C</smiles>

42<smiles>COCC(COC)n1cc(Br)nc(Nc2cc(C)c(O[14CH3])cc2C)c1=O</smiles>

43<smiles>COC[C@H](C1CC1)n1cc(Cl)nc(Nc2cc(C)c(OC)cc2C)c1=O</smiles>

44<smiles>COCC(COC)n1cc(Br)nc(Nc2c(C)cc(OC[18F])cc2C)c1=O</smiles>

45<smiles>COCC(COC)n1cc(Cl)nc(Nc2c(Cl)cc(OC[18F])cc2Cl)c1=O</smiles>

46

Figure 7. Small-molecule ligands at CRFR1.

42 2-(mesityloxy)-3,6-dimethyl-N-(pentan-3-yl)pyridin-4-amine; 43 5-bromo-1-(1,3-dimethoxypropan-2-yl)-3-((4-(ethoxy- $\left.{ }^{11} \mathrm{C}\right)$-2,5-dimethylphenyl)amino)pyrazin-2(1H)-one; 44 (R)-5-chloro-1-(1-cyclopropyl-2-methoxyethyl)-3-((4-methoxy-2,5-dimethylphenyl) amino)pyrazin-2(1H)-one; 45 5-bromo-1-(1,3-dimethoxypropan-2-yl)-3-((4-((fluoro$\left.{ }^{18} \mathrm{~F}\right)$ methoxy)-2,6-dimethylphenyl)amino) pyrazin-2(1H)-one; 46 5-chloro-3-((2,6-dichloro-4-((fluoro- $\left.{ }^{18} \mathrm{~F}\right)$ methoxy)phenyl)amino)-1-(1,3-dimethoxy-propan-2-yl)pyrazin-2(1H)-one. 
Doré et al. [61] identified the binding mode of CP376395 in a mutagenesis approach as an allosteric interaction at the transmembrane domain.

Although the most drug developments focus on the role of the receptor in neuronal cells, some investigations asked also for potential roles and hyper-expression of the CRFR1 in microglia [23] [33] [34] [64]. Such approaches are concerned, currently, rather with spinal cord diseases or pathophysiological reactions than with brain diseases [23] [33] [64].

First in vivo trials by Sullivan et al. with the CRFR1 ligand R121919 (2007) [58] could not confirm, finally, the suitability of the tracer also in brain PET imaging of primates and monkey.

During the last years several groups proposed further lead structures and modified physicochemical properties for better uptake across the BBB. Density of CRF1 receptors is the highest in pituitary gland (302 fmol/mg protein) [120]. However, localizations with $\mathrm{B}_{\max }$ interesting for PET in vivo imaging have been found also in cerebral cortex and cerebellum [120]. Lodge et al. [120] (Bristol-Myers-Squibb) developed a series of phenylamino pyrazinons with binding potentials $\left(\mathrm{B}_{\max } / \mathrm{K}_{\mathrm{d}}\right)$ up to 15 in in vitro tests with brain sections of rat and monkey (Figure 7, $\{44\}\{45\}\{46\}$ ). Several compounds showed appropriate $\log D$ and $\mathrm{IC}_{50}$ values. Two F-18-labelled compounds (Figure $7\{45\}\{46\}$ ) (Table 2) were tested in vitro and in vivo in rat and monkey. But the promising binding potentials of in vitro investigations could not be confirmed in vivo [120]. The authors presume three possible reasons for this mismatch, which are: potential concurrence of endogenous peptides at the binding site of the receptor in vivo with slow binding related to relatively fast elimination of the exogenous ligand; allosteric modulation of the receptor in vivo and potentially stressful conditions during the in vivo measurements influencing the binding behavior [120].

Stehouwer et al. [121] created a series of dihydropryridin-pyrazinones (Figure 8; $\{47\}\{48\}\{49\}\{50\}\{51\}$ ) (Table 2) and designed two of these as optimized PET tracers with high affinity to CRF1R and $\log P$ 2.2. First investigation in cynomouglus brain, finally, resulted in a low brain uptake. Inhibition of Pgp was not further tested. In 2017, the group proposed the fluoalkyl pyrazinon BMS 6650553 [122] [123] (Figure 8 \{52\}) (Table 2) as a further development derived from the original series.

\section{Conclusions and Challenges}

CX3CR1 is widely accepted and used as an immune histological marker of microglia population of the brain, whereas distribution of neuropeptide receptors, here with the examples of orexin, NPY and CRF receptors, is only poorly investigated for this type of cells.

Additionally to this background, a new approach to the functional role of the different parts of the brain and of its cellular components gains space. The reports by Herculano-Houzel and Azevedo [14] [15] revoking the portrayal of cellular composition of the brain, generally accepted for long time, challenges also the possibilities of PET approaches and the interpretation of their results. 
<smiles>CCCCN(CC)c1cc(C)nc2c1NC(=O)CN2c1ccc(Br)cc1Br</smiles>

47<smiles>CCCCN(CC)c1cc(C)nc2c1NC(=O)CN2c1ccc(C(C)C)cc1Br</smiles>

48<smiles>CCCCN(CC)c1cc(C)nc2c1NC(=O)CN2c1ccc(Br)cc1CC</smiles>

49<smiles>Cc1cc(N(C)C)c2c(n1)N(CCC[18F])C(=O)CN2c1ccc(C(C)C)cc1Br</smiles>

51<smiles>Cc1cc(N(C)C)c2c(n1)N(c1ccc(C(C)C)cc1Br)CC(=O)N2CCCC[18F]</smiles>

50<smiles>CC(C1CC1)n1cc(Cl)nc(Nc2c(Cl)cc(OC(F)(F)F)cc2Cl)c1=O</smiles>

52

Figure 8. Small-molecule ligands at CRFR1.

47 8-(butyl(ethyl)amino)-4-(2,4-dibromophenyl)-6-methyl-3,4-dihydropyrido[2,3-b]pyrazin2(1H)-one; 48 4-(2-bromo-4-isopropylphenyl)-8-(butyl(ethyl)amino)-6-methyl-3,4-dihydropyrido[2,3-b]pyrazin-2(1H)-one; 49 4-(4-bromo-2-ethylphenyl)-8-(butyl(ethyl)amino)-6-methyl-3,4-dihydropyrido[2,3-b]pyrazin-2(1H)-one; 50 4-(2-bromo-4-isopropylphenyl)-8-(dimethylamino)-1-(4-(fluoro-18F)butyl)-6-methyl-3,4-dihydropyrido[2,3-b]pyrazi n-2(1H)-one; 51 4-(2-bromo-4-isopropylphenyl)-8-(dimethylamino)-1-(3-(fluoro- $\left.{ }^{18} \mathrm{~F}\right) \mathrm{p}$ ropyl)-6-methyl-3,4-dihydropyrido[2,3-b]pyrazin-2(1H)-one; 52 (S)-5-chloro-1-(1-cyclopropylethyl)-3-((2,6-dichloro-4-(2,2-difluoroethoxy)phenyl)amino)pyrazin-2(1H)-one.

Also questions on variations in the regional role of microglia [124], especially, between cerebellum and cortex get first detailed answers with some scientific dynamics [125] [126] [127]. First studies in mice demonstrated that microglias of the cerebellum are less ramified than in cerebral cortex but are distributed more sparsely compared to the cortex. Stowell et al. [45] postulated that changed morphology and occurrence together with some functional properties of microglia could alter the efficacy of surveillance of the neuronal population in the cerebellum. Ayata et al. [125] postulated that microglia are responsible for a higher degree of cell death in cerebellum compared to cortical regions of the brain. They suggested that a decrease of cell death can trigger a change of the pheno- 
type of microglia and support fine-tuning of its clearance function for removal of dying neurons. With several mouse models it has been confirmed now that cerebellum shows high number of neuronal cells, comparable with that of striatum or hippocampus, but a markedly faster reduction of neurons during adulthood [125] [127] and functional properties of microglia similar to such in neurodegenerative diseases. The high phagocytotic activity typical for cerebellar microglia is suppressed in striatum and hippocampus. Finally, the "new" distribution of the cellular population in the brain reflects not only new local priorities of neurons but also of non-neuronal cells, especially of microglia.

A functional aspect which meets one key role of this part of cell population is the increasing inflammatory property of microglia during aging [128]. This can result in a hypersensitive response to stress in aged patients and alters requirements to therapy under such conditions [126] as well as for the tolerance to implants [129] and gives the item personalized therapy an even higher priority.

The density of microglial neuropeptide receptors or even of the chemokine receptor $\mathrm{CX} 3 \mathrm{CR}$ is described, as well as hitherto, half-quantitatively with antibodies or mRNA measurements (Table 1) which hampers access to the quantitative comparison of neuronal and microglia receptors. Trials to test correlations between expression of receptor protein and formation of mRNA have been undertaken rather for classical receptors like dopamine receptors by Araki et al. [130]. The authors found a good correlations between dopamine 1 receptor mRNA and the receptor protein.

Although microglia cultures are not easy to obtain and to maintain, meanwhile, they are available in several working groups opening the possibilities to obtain quantitative data also on receptor protein expression. Moreover, trascriptoms of special subtypes of microglia are determined in regional tissue sections, allowing detailed evaluation of functional specificities in the respective brain regions.

For orexin receptors and CRF receptor subtype 1, densities in the range of 100 $\mathrm{fmol} / \mathrm{mg}$ protein have been measured. Sullivan et al. [58] suggested this range as potentially sufficient for PET visualization with reference to a similar extent for serotonin receptors, where PET has been performed with success.

The developed small-molecule candidates of PET tracers for CRFR1, orexin receptors and NPY1 and 2 receptors could be helpful tools for such evaluations even before they are introduced as PET diagnostics. However, the complex binding behavior of endogenous agonists of CRFR1 might be a challenge for modelling of small-molecule ligands as candidates for drugs or diagnostic tools.

The more complicate question of a specific CX3CR1 antagonist with appropriate physicochemical properties necessary for brain PET might need rather the interdisciplinary approach of molecular modelling. This would be also a tribute to the complex structure of the endogenous ligands of chemokine receptors. Moreover, modelling in present crystal structures of CRFR1 and orexin receptors could facilitate understanding and pharmacophore development of Class A 
and $\mathrm{B} 1$ receptor ligands as allosteric or orthosteric effectors. A special challenge to in vivo visualization methods stays mapping of cerebellar structures [131] and exact identification of its regional binding places with view to both, classical GPCR s and receptors with more complicate extracellular binding domains.

\section{Conflicts of Interest}

The author declares no conflicts of interest regarding the publication of this paper.

\section{References}

[1] Lee, Y., Basith, S. and Choi, S. (2018) Recent Advances in Structure-Based Drug Design Targeting Class A G-Protein Coupled Receptors Utilizing Crystal Structures and Computational Simulations. Journal of Medicinal Chemistry, 61, 1-46. https://doi.org/10.1021/acs.jmedchem.6b01453

[2] Hu, G.-M., Mai, T.-L. and Chen, C.-M. (2017) Visualization of the GPCR Network: Classification and Evolution. Scientific Reports, 7, Article No. 15495. https://doi.org/10.1038/s41598-017-15707-9

[3] Hauser, A.S., Attwood, M.M., Rask-Andersen, M., Schiöth, H.B. and Gloriam, D.E. (2017) Trends in GPCR Drug Discovery: New Agents, Targets and Indications. Nature Reviews Drug Discovery, 16, 829-842. https://doi.org/10.1038/nrd.2017.178

[4] Lodowski, D.T. and Palczewski, K. (2009) Chemokine Receptors and Other GPCRs. Current Opinion in HIV and AIDS, 4, 88-95. https://doi.org/10.1097/COH.0b013e3283223d8d

[5] Blankeney, J.S., Reid, R.C., Le, G.T. and Fairlie, P. (2007) Nonpeptidic Ligands for Peptide-Activated G Protein-Coupled Receptors. Chemical Reviews, 107, 2960-3041. https://doi.org/10.1021/cr050984g

[6] Hauser, A.S., Chavali, S., Masuho, I., Jahn, M.J., Martemyanov, K.A., Gloriam, D.E. and Babu, M.M. (2018) Pharmacogenomics of GPCR Drug Targets. Cell, 172, 41-54. https://doi.org/10.1016/j.cell.2017.11.033

[7] Parthier, C., Reetz-Runge, S., Rudolf, R. and Stubbs, M.B. (2009) Passing the Baton in Class B GPCRs: Peptide Hormone Activation via Helix Induction. Trends in Biochemical Science, 34, 304-310. https://doi.org/10.1016/j.tibs.2009.02.004

[8] Pasznik, P., Rutkowska, E., Niewieszerza, S., Cielecka-Piontek, J. and Latek, D. (2019) Potential Off-Target Effects of B-Blockers on Gut Hormone Receptor: In Silico Study Including Gut Dock-A Web Service for Small Molecule Docking. PLoS ONE, 14, e0210705. https://doi.org/10.1371/journal.pone.0210705 https://journals.plos.org/plosone/article?id=10.1371/journal.pone.0210705

[9] Valadas, J.S., Bathalha, V.L., Ferreira, D.G., Gomes, R., Cohelo, J.A., Sebastiao, A.M., Diogenes, M.J. and Lopes, L.V. (2012) Neuroprotection Afforded by Adenosine 2a Receptor Blockade is Modulated by Corticotrophin Releasing Factor Receptor in Glutamate Injured Cortical Neurons. Journal of Neurochemistry, 123, 1030-1040. https://doi.org/10.1111/jnc. 12050

[10] Norden, D.M. and Godbout, J.P. (2013) Microglia of the Aged Brain: Primed to Be Activated and Resistant to Regulation. Neuropathology and Applied Neurobiology, 39, 19-34. https://doi.org/10.1111/j.1365-2990.2012.01306.x

[11] Mittelbronn, M., Dietz, K., Schluesener, H.J. and Meyermann, R. (2001) Local Distribution of Microglia in the Normal Adult Central Nervous System Differs by Up 
to One Order of Magnitude. Acta Neuropathologica, 101, 249-255.

[12] Lawson, L.J., Perry, V.H., Dri, P. and Gordon, S. (1990) Heterogeneity in the Distribution and Morphology of Microglia in the Normal Adult Mouse Brain. Neuroscience, 39, 151-170. https://doi.org/10.1016/0306-4522(90)90229-W

[13] Herculano-Houzel, S. and Lent, R. (2005) Isotropic Fractionator: A Simple, Rapid Method for the Quantification of Total Cell and Neuron Numbers in the Brain. Journal of Neuroscience, 25, 2518-2521. https://doi.org/10.1523/JNEUROSCI.4526-04.2005

[14] Herculano-Houzel, S. (2009) Human Brain in Numbers: A Linearly Scaled-Up Primate Brain. Frontiers in Human Neuroscience, 3, Article 31. https://doi.org/10.3389/neuro.09.031.2009

[15] Azevedo, F.A.C., Carvalho, L.R.B., Grinberg, L.T., Farfel, J.M., Ferretti, R.E.L., Leite R.E.P., Filho, W.J., Lent, R. and Herculano-Houzel, S. (2009) Equal Numbers of Neuronal and Nonneuronal Cells Make the Human Brain and Isometrically Scaled-Up Primate Brain. Journal of Comparative Neurology, 513, 532-541. https://doi.org/10.1002/cne.21974

[16] Hughes, C.E and Nibbs, R.J. (2018) A Guide to Chemokines and Their Receptors. FEBS Journal, 285, 2944-2971. https://doi.org/10.1111/febs.14466

[17] Nishiyori, A. Minami, M., Othani, Y., Takami, S., Yamamoto, J., Kawaguchi, N., Kume, T., Akaike, A. and Satoh, M. (1998) Localization of Fraktalkine and CX3CR mRNA in Rat Brains: Does Fraktalkine Play a Role in Signaling from Neuron to Microglia. FEBS Letters, 429, 167-172. https://doi.org/10.1016/S0014-5793(98)00583-3

[18] Hervieu, G.J., Cluderay, J.E., Harrison, D.C., Roberts, J.C. and Leslie, R.A. (2001) Gene Expression and Protein Distribution of the Orexin-1-Receptor in the Rat Brain and Spinal Cord. Neuroscience, 103, 777-797. https://doi.org/10.1016/S0306-4522(01)00033-1

[19] Mihara, Y., Dohi, K., Yofu, S., Nakamachi, T., Othaki, H., Shioda, S. and Aruga, T. (2011) Expression and Localization of Orexin-1-Receptor (OX1R) after Traumatic Brain Injury in Mice. Journal of Molecular Neuroscience, 43, 162-168. https://doi.org/10.1007/s12031-010-9438-6

[20] Carniglia, L., Ramirez, D., Durand, D. Saba, J., Turati, J., Caruso, C., Scimonelli, T.N. and Lasaga, M. (2017) Neuropeptides and Microglial Activation in Inflammation, Pain and Neurodegenerative Diseases. Mediators of Inflammation, 2017, Article ID: 5048616. https://doi.org/10.1155/2017/5048616

[21] Santos-Carvalho, A., Aveleira, C.A., Elvas, F., Abrosio, A.F. and Cavadas, C. (2013) Neuropeptide Y Receptors NPY1 and NPY2 Are Present in Neurons and Glia Cells in Rat Retinal Cells and Culture. Investigative Ophthalmology \& Visual Science, 54, 429-443. https://doi.org/10.1167/iovs.12-10776

[22] Ferreira, R., Santos, T., Cortes, L., Cochaud, S., Agasse, F., Silva, A.P., Xapelli, S. and Malva, J.O. (2012) Neuropeptide Y Inhibits Interleukin-1 Beta-Induced Microglia Motility. Journal of Neurochemistry, 120, 93-105. https://doi.org/10.1111/j.1471-4159.2011.07541.x

[23] Kim, E.H., Ryu, D.H. and Hwang, S. (2011) The Expression of Corticotropin-Releasing Factor and Its Receptors in Spinal Cord and Dorsal Ganglion in a Rat Model of Neuropathic Pain. Anatomy \& Cell Biology, 44, 60-68. https://doi.org/10.5115/acb.2011.44.1.60

[24] Greter, M., Lellios, I. and Croxford, A.L. (2015) Microglia versus Myeloid Cell Nomenclature during Brain Inflammation. Frontiers in Immunology, 6, Article 249. 
https://doi.org/10.3389/fimmu.2015.00249

[25] Szepesi, Z., Manouchehrian, O., Bachiller, S. and Deierborg, T. (2018) Bidirectional Microglia-Neuron Communication in Health and Disease. Frontiers in Cellular Neuroscience, 12, Article 323. https://doi.org/10.3389/fncel.2018.00323

[26] Kettenmann, H., Hanisch, U.-K., Noda, M. and Verkhratsky, A. (2011) Physiology of Microglia. Physiological Reviews, 91, 461-553. https://doi.org/10.1152/physrev.00011.2010

[27] Hickmann, S.E., Kingery, N.D., Ohsumi, T.K., Borows, M.I., Wang, L.-C., Means, T.K. and El Khoury, J. (2013) The Microglial Sensome Revealed by Direct RNA Sequencing. Nature Neuroscience, 16, 1896-1905. https://doi.org/10.1038/nn.3554

[28] Grabert, K., Michoel, T., Karavolos, M.H., Clohisey, S., Baillie, J.K., Stevens, M.P., Freeman, T.C., Summers, K.M. and McColl, B.W. (2016) Microglial Brain-Region Dependent Diversity and Selective Regional Sensitivities to Aging. Nature Neuroscience, 19, 504-516. https://doi.org/10.1038/nn.4222

[29] Segal, B.M. and Giger, R.J. (2016) Stable Biomarker for Plastic Microglia. PNAS, 113, 3130-3132. https://doi.org/10.1073/pnas.1601669113

[30] Sellgren, C.M., Gracias, J., Watmuff, B., Biag, J.D., Thanos, J.M., Wittredge, P.B., Worringer, K., Shaham, Y. and de Wit, H. ( 2016) Lost in Translation: CRF1 Receptor Antagonist and Addiction Treatment. Neuropsychopharmacology, 41, 2795-2797. https://doi.org/10.1038/npp.2016.94

[31] Herclano-Houzel, S. (2011) Scaling of Brain Metabolism with a Fixed Energy Budget per Neuron: Implications for Neuronal Activity, Plasticity and Evolution. PLoS ONE, 6, e17514. https://doi.org/10.1371/journal.pone.0017514

[32] Herculano-Houzel, S. (2014) The Glia/Neuron Ratio: How It Varies Uniformly across Brain Structures and Species and What Means for Brain Physiology and Evolution. Glia, 62, 1377-1391. https://doi.org/10.1002/glia.22683

[33] Akhmetzyanova, E.R., Mukhamedshina, Y.O., Zhuravleva, N.M., Galieva, L.R., Kostennikov, A.A., Garanina, E.E. and Rizvanov, A.A. (2018) Transplantation of Microglia in the Area of Spinal Cord Injury in an Acute Period Increases Tissue Sparing, But Not Functional Recovery. Frontiers in Cellular Neuroscience, 12, 507. https://doi.org/10.3389/fncel.2018.00507

[34] Green, L.A., Nebiolo, J.C. and Smith, C.J. (2019) Microglia Exit the CNS in Spinal Root Avulsion. PLoS Biology, 17, e3000159. https://doi.org/10.1371/journal.pbio.3000159

[35] Tronel, C., Largeau, B., Ribeiro, M.J.S., Guilloteau, D., Dupont, A.-C. and Arlicot, N. (2017) Molecular Target for PET Imaging of Activated Microglia: The Current Situation and Future Expectations. International Journal of Molecular Sciences, 18, 802. https://doi.org/10.3390/ijms18040802

[36] Özen, I., Deierborg, T., Miharada, K., Padel, T. and Englund, E. (2014) Brain Pericytes Aquire a Microglial Phenotype after Stroke. Acta Neuropathologica, 128, 381-396. https://doi.org/10.1007/s00401-014-1295-x

[37] Sperlagh, B. and Illes, P. (2007) Purinergic Modulation of Microglial Cell Activation. Purinergic Signalling, 3, 117-127. https://doi.org/10.1007/s11302-006-9043-X

[38] Geloso, M.C., Corvino, V., Marchese, E., Serrano, R., Michetti, F. and D'Ambrosi, N. (2017) The Dual Role of Microglia in ALS: Mechanisms and Therapeutic Approaches. Frontiers in Aging Neuroscience, 9, Article 242. https://doi.org/10.3389/fnagi.2017.00242

[39] Sheridan, G.K. and Murphy, K.J. (2013) Neuron-Glia Cross Talk in Health and Disease: Fractalkine and CX3CR1 Central Stage. Open Biology, 3, Article ID: 130181. 
https://doi.org/10.1098/rsob.130181

[40] Pandy-Szekeresz, G., Munk, C., Tsonkov, T.M., Mordalski, S., Harpso, K., Hauser, A.S., Bojarski, A.J. and Gloriam, D.E. (2018) GPCRdb in 2018: Adding GPCR Structure Models and Ligands. Nucleic Acid Research, 46, D440-D446. https://doi.org/10.1093/nar/gkx1109

[41] Munk, C., Isberg, V., Mordalski, S., Harpsoe, K., Rataj, K., Hauser, A.S., Kolb, P., Bojarski, A.J., Vriend, G. and Gloriam, D.E. (2016) The GPCRdb: G-Protein Coupled Receptor Database-An Introduction. British Journal of Pharmacology, 173, 2195-2207. https://doi.org/10.1111/bph.13509

[42] Karlström, S., Nordvall, G., Sohn, D., Hettman, A., Turek, D., Ahlin, K., Kers, A., Claesson, M., Slivo, C., Lo-Alfredsson, Y., Petersson, C., Bessidskaia, G., Svensson, P.H., Rein, T., Jerning, E., Malmber, A., Algen, C., Ray, C., Vares, L., Ivanov, V. and Johansson, R. (2013) Substituted 7-Amino-5-Thio-Thiazolo [4,5-d]Pyrimidines as Potent and Selective Antagonists of the Fractalkine Receptor (CX3CR1). Journal of Medicinal Chemistry, 56, 3177-3190. https://doi.org/10.1021/jm3012273

[43] Cederblad, L., Rosengreen, B., Ryberg, E. and Hermansson, N.-O. (2016) AZD8797 Is an Allosteric Non-Competitive Modulator of the Human CX3CR1 Receptor. Biochemical Journal, 473, 641-647. https://doi.org/10.1042/BJ20150520

[44] Basile, A. and Skolnick, P. (1986) Subcellular Localization of "Peripheral-Type" Binding Sites for Benzodiazepines in Rat Brain. Journal of Neurochemistry, 46, 305-308. https://doi.org/10.1111/j.1471-4159.1986.tb12965.x

[45] Stowell, R.D., Wong, E.L., Batchelor, H.N., Mendes, M.S., Lamantia, C.E., Whitelaw, B.S. and Mendes, A.K. (2017) Cerebellar Microglia Are Dynamically Unique and Survey Purkinje Neurons in Vivo. Developmental Neurobiology, 78, 627-644. https://doi.org/10.1002/dneu.22572

[46] Bartanusz, V., Jezova, D., Alajajian, B. and Digicaylioglu, M. (2011) The Blood Spinal Cord Barrier: Morphology and Clinical Implications. Annals of Neurology, 70, 194-206. https://doi.org/10.1002/ana.22421

[47] Lorenzen, E., Dodig-Crnkovic, T., Kotliar, I.B., Pin, E., Ceraudo, E., Vaughan, O.D., Uhlen, M., Huber, T., Schwenk, J.M. and Sakmar, T.P. (2019) Multiplexed Analysis of the Secretin-Like GPCR-RAMP Interactom. https://doi.org/10.1101/597690

[48] Wu, F., Song, G., De Graaf, C. and Stevens, R.C. (2017) Structure and Function of Peptide-Binding G-Protein Coupled Receptors. Journal of Molecular Biology, 420, 2726-2745. https://doi.org/10.1016/j.jmb.2017.06.022

[49] Mease, R., Yang, X., Foss, C. and Pomper, M. (2015) Radiosynthesis and Initial in Vivo Evaluation of 2-[18F]FBTTP, a Radiotracer Targeting CX3CR1. Journal of Nuclear Medicine, 56, 356.

[50] Hostetler, E.D., Sanabria-Bohorquez, S., Fan, H., Zeng, Z., Gantert, L., Williams, M., Miller, P., O’Malley, S., Kameda, M., Ando, M., Sato, N., Ozaki, S., Tokita, S., Otha, H., Williams, D., Sur, C., Cook, J.J., Burns, H.D. and Hargreaves, R. (2011) Synthesis, Characterization, and Monkey Positron Emission Tomography (PET) Studies of [18F]Y1-973, a PET Tracer for the Neuropeptide YY1 Receptor. Neuroimage, 54, 2635-2642. https://doi.org/10.1016/j.neuroimage.2010.11.014

[51] Poniatowski, L.A., Woidasiewicz, P., Krawzyk, M., Sziukiewicz, D., Gasik, R., Kubaszewski, L. and Kurkowska-Jastrzebska, I. (2017) Analysis of the Role of CX3CL1 (Fractalkine) and Its Receptor CX3CR1 in Traumatic Brain and Spinal Cord Injury: Insight into Recent Advances in Actions of Neurochemokine Agents. Molecular Neurobiology, 54, 2167-2188. https://doi.org/10.1007/s12035-016-9787-4

[52] Freria, C.M., Hall, J.C.E., Wei, P., Guan, Z. M.C., Tigue, D.M. and Popovich, P.G. 
(2017) Deletion of the Fractalkine Receptor CX3CR Improves Endogenous Repair, Axon Sprouting, and Synaptogenesis after Spinal Cord Injury in Mice. Journal Neuroscience, 37, 3568-3587. https://doi.org/10.1523/JNEUROSCI.2841-16.2017

[53] Bellver-Landete, V., Brethau, F., Mailhot, B., Vallier, N., Lessard, M., Jaselle, M.-E., Vernoux, M., Tremblay, M.-E., Fuehrmann, T., Shoichet, M.S. and Lacroix, S. (2019) Microglia Are an Essential Component of the Neuroprotective Scar That Forms after Spinal Cord Injury. Nature Communications, 10, 518.

https://doi.org/10.1038/s41467-019-08446-0

[54] Statnick, M.A., Schober, D.A., Mayne, N.G., Burnett, J.P. and Gehlert, D.R. (1997) Analysis of NPY Receptor Subtypes in the Human Frontal Cortex Reveals Abundant Y1 mRNA and Binding Sites. Peptides, 18, 137-143. https://doi.org/10.1016/S0196-9781(96)00246-X

[55] Schober, D.A., Gackenheimer, S.L., Heiman, M.L. and Gehlert, D.R. (2000) Pharmacological Characterization of 125I-1229U91 Binding to Y1 and Y4 Neuropeptide Y/Peptide YY Receptors. Journal of Pharmacology and Experimental Therapeutics, 293, 275-280.

[56] Monti, J.M., Spence, D.W., Butoo, K. and Pandi-Perumal, S.R. (2017) Zolpidem's Use for Insomnia. Asian Journal of Psychiatry, 25, 79-90. https://doi.org/10.1016/j.ajp.2016.10.006

[57] Riemann, D., Baglioni, C., Bassetti, C., Bjorvatn, B., Groselj, L.D., Ellis, J.G., Espie, C.A., Garcia-Borreguero, D., Gjerstad, M., Goncalves, M., Hertenstein, E., Jansson-Frömark, M., Jennum, P.J., Leger, D., Nissen, C., Parrino, L., Paunio, T., Pevernagie, D., Verbraecken, J., Weeb, H.G., Wichniak, A., Zavalko, I., Arnadottir, E.S., Deleanu, O.-C., Strazisar, B., Zoetmulder, M. and Spiegelhalder, K. (2017) European Guideline for the Diagnosis and Treatment of Insomnia. Journal of Sleep Research, 26, 675-700. https://doi.org/10.1111/jsr.12594

[58] Sullivan, G.M, Parsey, R.V., Kumar, J.S.D., Arango, V., Kassir, S.A., Huang, Y.-Y., Simpson, N.R., van Heertum, R.L. and Mann, J.J. (2007) PET Imaging of CRF1 with [11C]R121920 and DMP696: Is the Target of Sufficient Density? Nuclear Medicine and Biology, 34, 353-361. https://doi.org/10.1016/j.nucmedbio.2007.01.012

[59] Hollenstein, A., Kean, J., Bortolato, A., Cheng, R.K.Y., Doré, A.S., Jazayeri, A., Cooke, R.M., Weir, M. and Marshall, F.H. (2013) Structure of Class B GPCR Corticotrophin Releasing Factor 1 Receptor. Nature, 499, 438-445. https://doi.org/10.1038/nature12357

[60] Bai, Q., Shi, D., Zhang, Y., Liu, H. and Yao, X. (2014) Exploration of the Antagonist CP376395 Escape Pathway of Corticotrophin Releasing Factor1 by Random Acceleration by Molecular Dynamics Simulation. Molecular Biosystems, 10, 1958. https://doi.org/10.1039/c4mb00037d

[61] Doré, A.S., Bortolato, A., Hollenstein, K., Cheng, R.K.Y., Read, R.J. and Marshall, F.H. (2017) Decoding Corticotropin-Releasing Factor Receptor Type 1 Crystal Structure. Current Molecular Pharmacology, 10, 334-344. https://doi.org/10.2174/1874467210666170110114727

[62] Cavasotto, C.N. and Palomba, D. (2015) Expanding the Horizon of G Protein-Coupled Receptor Structure-Based Ligand Discovery and Optimization Using Homology Models. Chemical Communications, 51, 13576-13594. https://doi.org/10.1039/C5CC05050B

[63] Burkert, K., Zellman, T., Meier, R., Kaiser, A., Stichel, J., Meiler, J., Mittapalli, G.K., Roberts, E. and Beck-Sickinger, A.G. (2017) A Deep Hydrophobic Binding Cavity Is the Main Interaction for Different Y2R Antagonist. ChemMedChem, 12, 75-85. 
https://doi.org/10.1002/cmdc.201600433

[64] Kim, H., Choi, B., Lim, H., Min, H., Oh, J.H., Choi, S., Cho, J.G., Park, J.-S. and Lee, S.J. (2017) Polyamidoamine Dendrimer-Conjugated Triamcinolone Acetonide Attenuates Nerve Injury-Induced Spinal Cord Microglia Activation and Molecular Allodynia. Molecular Pain, 13, 1-11. https://doi.org/10.1177/1744806917697006

[65] Weiss, S., Keller, M., Bernhardt, G., Buschauer, A. and König, B. (2010) NG-AcylArgininamides as NPY Y1 Receptor Antagonists: Influence of Structurally Diverse Acyl Substituents on Stability and Affinity. Bioorganic \& Medicinal Chemistry, 18, 6292-6304. https://doi.org/10.1016/j.bmc.2010.07.028

[66] Keller, M., Schindler, L., Bernhardt, G. and Buschauer, A. (2015) Toward Labeled Argininamide-Type NPYY1 Receptor Antagonists: Identification of a Favorable Propionylation Site in BIBO3304. Arch. Pharm. Chemistry in Life Sciences, 348, 390-398. https://doi.org/10.1002/ardp.201400427

[67] Keller, M., Maschauer, S., Brennauer, A., Tripal, P., Koglin, N., Dittrich, R., Bernhardt, G., Kuwert, T., Wester, H.-J., Buschauer, A. and Prante, O. (2017) Prototypic 18F-Labeled Argininamide-Type Neuropeptide Y Y1 R Antagonists as Tracers for PET Imaging of Mammary Carcinoma. ACS Medicinal Chemistry Letters, 8, 304-309. https://doi.org/10.1021/acsmedchemlett.6b00467

[68] Lipinski, C.A. (2000) Drug-Like Properties and the Causes of Poor Solubility and Poor Permeability. Journal of Pharmacological and Toxicological Methods, 44, 235-249. https://doi.org/10.1016/S1056-8719(00)00107-6

[69] Kawamura, K., Mori, W., Fujinaga, M., Yamasaki, T., Zhang, Y., Wakizaka, H., Hatori, A., Xie, L., Kumata, K., Okhubo, T., Kurihara, Y., Ogawe, M., Nengaki, N. and Zha, M.-R. (2019) Radiosynthesis and in Vivo Evaluation of ${ }^{11} \mathrm{C}$-Labelled BMS-193885 and Its Dimethyl Analogue as PET Tracers for Neuropeptide Y1 Receptor. EJNMMI Radiopharmacy and Chemistry, 4, 4. https://doi.org/10.1186/s41181-019-0056-5

[70] Winterdahl, M., Audrai, H., Landau, A.M., Smith, D.F., Bonaventur, P., Shoblock, J.R., Carruthers, N., Swanson, D. and Bender, D. (2014) PET Brain Imaging of Neuropeptide Y2 Receptors Using N- ${ }^{11} \mathrm{C}-$ Methyl-JNJ-31020028 in Pigs. Journal of Nuclear Medicine, 55, 635-639. https://doi.org/10.2967/jnumed.113.125351

[71] Shoblock, J.R., Welty, N., Nepomuceno, D., Lord, B., Aluisio, L., Fraser, I., Motley, S.T., Sutton, S.W., Morton, K., Galici, R., Dvorak, C., Lovenberg, T.W. and Bonaventure, P. (2010) In Vitro and in Vivo Characterization of JNJ-31020028 (N-(4-\{4-[2-(diethylamino)-2-oxo-1-phenylethylpiperazin-1-yl\}-3-fluorophenyl)-2pyridin-3-ylbenzamide), a Selective Brain Penetrant Small Molecule Antagonist of the Neuropeptide YY2 Receptor. Psychopharmacology, 208, 265-277.

https://doi.org/10.1007/s00213-009-1726-x

[72] Mitapalli, G.K. and Roberts, E. (2014) Ligands of the Neuropeptide YY2 Receptor. Bioorganic \& Medicinal Chemistry Letters, 24, 430-441.

https://doi.org/10.1016/j.bmcl.2013.11.061

[73] Lunniss, G.E., Barnes, A.A., Barton, N., Biagetti, M., Bianchi, F., Blowers, S.M., Caberlotto, L., Emmons, A., Holmes, I.P., Montanari, D., Norris, R., Walters, J.P. and Watson, S.P. (2009) The Identification and Optimization of Novel and Selective Diamide Neuropeptide Y Y2 Receptor Antagonists. Bioorganic \& Medicinal Chemistry Letters, 19, 4022-4025. https://doi.org/10.1016/j.bmcl.2009.06.035

[74] Dautzenberg, F.M. and Neysari, S. (2005) Irreversible Binding Kinetics of Neuropeptide Y Ligands to Y2 But Not to Y1 and Y5 Receptors. Pharmacology, 75, 21-24. https://doi.org/10.1159/000085897

[75] Kaiser, A., Müller., P, Zellmann, T., Scheidt, H.A., Thomas,L., Bosse, M., Meier, R., 
Meiler, J., Huster, D., Beck-Sickinger, A.G. and Schmidt, P. (2015) Unwinding of the C-Terminal Residues of Neuropeptide Y Is Critical for NPY2 Receptor Binding and Activation. Angewandte Chemie International Edition in English, 54, 7446-7449. https://doi.org/10.1002/anie.201411688

[76] Tikhonova, I.G., Gigoux, V. and Fourmy (2019) Understanding Peptide Binding in Class A G Protein-Coupled Receptors. Molecular Pharmacology, 119, Article ID: 115915. https://doi.org/10.1124/mol.119.115915

[77] Lemus, M.B., Bayliss, J.A., Lockie, S.H., Santos, V.V., Reichenbach, A., Stark, R. and Andrews, Z.B. (2015) A Stereological Analysis of NPY, POMC, Orexin, GFAP Astrocytes and Iba1 Microglia Cell Number and Volume in Diet-Induced Obese Male Mice. Endocrinology, 156, 1701-1713. https://doi.org/10.1210/en.2014-1961

[78] Pissarek, M. and Disko, U. (2013) Non-Peptide Ligands in the Characterization of Peptide Receptors at the Interface between Neuroendocrine and Mental Diseases. WJNS, 3, 100-125. https://doi.org/10.4236/wjns.2013.32014

[79] Roecker, A.J., Cox, C.D. and Coleman, P.J. (2016) Orexin Receptor Antagonists: New Therapeutic Agents for the Treatment of Insomnia. Journal of Medicinal Chemistry, 59, 504-530. https://doi.org/10.1021/acs.jmedchem.5b00832

[80] Lin, L., Faraco, J., Li, R., Kadothahi, Rogers, W., Lin, X., Qiu, X., de Jong, P.J., Nishino, S. and Mignot, E. (1999) The Sleep Disorder Canine Narcolepsy Is Caused by Mutation in the Hypocretin (Orexin) Receptor 2 Gene. Cell, 98, 365-376. https://doi.org/10.1016/S0092-8674(00)81965-0

[81] Toner, L.C., Tsambiras, B.M., Catalano, G., Catalano, M.C. and Cooper, D.S. (2000) Central Nervous System Side Effects Associated with Zolpidem Treatment. Clinical Neuropharmacology, 23, 54-58. https://doi.org/10.1097/00002826-200001000-00011

[82] Yang, W., Dollear, M. and Muthukrishnan, S.R. (2005) One Rare Side Effect of Zolpidem-Sleepwalking: A Case Report. Archives of Physical Medicine and Rehabilitation, 86, 1265-1266. https://doi.org/10.1016/j.apmr.2004.11.022

[83] Farkas, R.H., Unger, E.F. and Temple, R. (2013) Zolpidem and Driving Impairment-Identifying Persons at Risk. The New England Journal of Medicine, 369, 689-691. https://doi.org/10.1056/NEJMp1307972

[84] Strother, L.C., Srikiatkhachom, A. and Supronsinchai, W. (2018) Targeted Orexin and Hypothalamic Neuropeptides for Migraine. Neurotherapeutics, 15, 377-390. https://doi.org/10.1007/s13311-017-0602-3

[85] Wang, C., Wang, Q., Ji, B., Pan, Y., Xu, C., Cheng, B., Bai, B. and Chen, J. (2018) The Orexin/Receptor System: Molecular Mechanism and Therapeutic Potential for Neurological Diseases. Frontiers in Molecular Neuroscience, 11, Article 220. https://doi.org/10.3389/fnmol.2018.00220

[86] Mang, G.M., Dürst, T., Bürki, H., Imobersteg, S., Abramowski, D., Schuepbach, E., Hoyer, D., Fendt, M. and Gee, C.E. (2012) The Dual Orexin Receptor Antagonist Alomrexant Induces Sleep and Decreases Orexin-Induced Locomotion by Blocking Orexin 2 Receptors. Sleep, 35, 1625-1635. https://doi.org/10.5665/sleep.2232

[87] Bonaventure, P., Shelton, J., Yun, S., Nepomuceno, D., Sutton, S., Aluisio, L., Fraser, I., Lord, B., Shoblock, J., Welty, N., Chaplan, S.R., Agilar, Z., Halter, R., Ndifor, A., Koudriakova, T., Rizzolo, M., Letavic, M., Carruthers, N.I., Lovenberg, T. and Dugovic, C. (2015) Characterization of JNJ-42847922, a Selective Orexin-2 Receptor Antagonist, as a Clinical Candidate for the Treatment of Insomnia. Journal of Pharmacology and Experimental Therapeutics, 354, 471-482. https://doi.org/10.1124/jpet.115.225466

[88] Lopez, M.F., Moorman, D.E., Aston-Jones, G. and Becker, H.C. (2016) The Highly 
Selective Orexin/Hypocretin 1 Receptor Antagonist GSK 1059865 Potently Reduced Ethanol Drinking in Ethanol Dependent Mice. Brain Research, 1636, 74-80. https://doi.org/10.1016/j.brainres.2016.01.049

[89] Lawrence, A.J. (2010) Regulation of Alcohol Seeking by Orexin (Hypocretin) Neurons. Brain Research, 1314, 124-129. https://doi.org/10.1016/j.brainres.2009.07.072

[90] Smart, D., Sabido-David, C., Brough, S.J., Jewitt, F., Johns, A., Porter, R.A. and Jerman, J.C. (2001) SB-334867: The First Selective Orexin-1 Receptor Antagonist. British Journal of Pharmacology, 132, 1179-1182. https://doi.org/10.1038/sj.bjp.0703953

[91] Stump, C.A., Cooke, A.J., Bruno, J., Cabalu, T.D., Gotter, A.L., Harrell, C.M., Kuduk, S.D., McDonald, T.P., O’Brien, J., Renger, J.J., Williams, P.D., Winrow, C.J. and Coleman, P.J. (2016) Discovery of Highly Potent and Selective Orexin 1 Receptor Antagonists (1-SORA) Suitable for in Vivo Interrogation of Orexin 1 Receptor Pharmacology. Bioorganic \& Medicinal Chemistry Letters, 26, 5809-5814.

https://doi.org/10.1016/j.bmcl.2016.10.019

[92] Futamura, A., Nozawa, D., Araki, Y., Tamura, Y., Tokura, S., Kawamoto, H., Tokumaru, Y., Kakihara, S., Aoki, T. and Ohtake, N. (2017) Identification and Synthesis of Highly Selective Orexin 1 Receptor Antagonists Derived from a Dual Orexin Receptor $1 / 2$ Antagonist Based on the Structural Framework of Pyrazoylethylbenzamide. Bioorganic \& Medicinal Chemistry, 25, 5203-5215.

https://doi.org/10.1016/j.bmc.2017.07.051

[93] Nagase, H., Yamamoto, N., Yata, M., Ohrui, S., Okada, T, Saito, T., Kutsumura, N., Nagumo, Y., Iruknayama-Tomobe, Y., Ishikawa, Y., Ogawa, Y., Hirayama, S., Kuroda, D., Watanabe, Y., Gouda, H. and Yanasigawa, M. (2017) Design and Synthesis of Potent and Highly Selective Orexin 1 Receptor Antagonists with a Morphinan Skeleton and Their Pharmacologies. Journal of Medicinal Chemistry, 60, 1018-1040. https://doi.org/10.1021/acs.jmedchem.6b01418

[94] Yin, J., Babaoglu, K., Brautigam, C.A., Clark, L., Shao, Z., Scheuermann, T.H., Harrell, C.M., Gotter, A.L., Roecker, A.J., Winrow, C.J., Renger, J.J., Coleman, P.J. and Rosenbaum, D.M. (2016) Structure and Ligand Binding Mechanism of the Human OX1 and OX2 Receptors. Nature Structural \& Molecular Biology, 23, 293-299. https://doi.org/10.1038/nsmb.3183

[95] Hirose, M., Egashira, S.-I., Goto, Y., Hashihayata, T., Ohtake, N., Iwaasa, H., Hata, M., Fukami, T., Kanatani, A. and Yamada, K. (2003) N-Acyl-6,7-Dimethoxy-1,2,3,4 Tetrahydroisoquinoline. The First Orexin 2 Receptor Selective Nonpeptidic Antagonist. Bioorganic \& Medicinal Chemistry Letters, 13, 4497-4499. https://doi.org/10.1016/j.bmcl.2003.08.038

[96] Mensch, J., Oyarzabal, J., Mackie, C. and Augustijins, P.J. (2009) In Vivo, in Vitro and in Silico Methods for Small Molecule Transfer across the BBB. Pharmaceutical Sciences, 98, 4429-4468. https://doi.org/10.1002/jps.21745

[97] Fujimoto, T., Tomata, Y., Kunitomo, J., Hirozane, M. and Marui, S. (2011) Discovery of Spiropiperidine-Based Potent and Selective Orexin 2 Receptor Antagonists. Bioorganic \& Medicinal Chemistry Letters, 21, 6409-6413. https://doi.org/10.1016/j.bmcl.2011.08.094

[98] Betschart, C., Hintermann, S., Behnke, D., Cotesta, S., Fendt, M., Gee, C.E., Jacobson, L.H, Laue, G., Ofner, S., Chaudhari, V., Badiger, S., Pandit, C., Wagner, J. and Hoyer, D. (2013) Identification of a Novel Series of Orexin Receptor Antagonists with a Distict Effect on Sleep Architecture for the Treatment of Insomnia. Journal of Medicinal Chemistry, 56, 7590-7607. https://doi.org/10.1021/jm4007627

[99] Wang, C., Wilson, C.M., Moseley, C.K., Carlin, S.M., Hsu, S., Arabasz, G., Schroed- 
er, F.A., Sander, C.Y. and Hooker, J.M. (2013) Evaluation of Potential PET Imaging Probes for the Orexin 2 Receptor. Nuclear Medicine and Biology, 40, 1000-1005. https://doi.org/10.1016/j.nucmedbio.2013.07.001

[100] Malherbe, P., Borroni, E., Gobbi, L., Knust, H., Nettenkoven, M., Pinard, E., Roche, O., Evans, R.M., Wettstein, J.G. and Moreau, J.-L. (2009) Biochemical and Behavioral Characterization of EMPA, a Novel High-Affinity, Selective Antagonist for the OX2 Receptor. British Journal of Pharmacology, 156, 1326-1341. https://doi.org/10.1111/j.1476-5381.2009.00127.x

[101] Schwab, M., Bauer, R. and Zwiener, U. (1997) The Distribution of Normal Brain Water Content in Wistar Rats and Its Increase Due to Ischemia. Brain Research, 749, 82-87. https://doi.org/10.1016/S0006-8993(96)01165-1

[102] Kogure, K., Busto, R., Scheinberg, P. and Reinmuth, O.M. (1974) Energy Metabolites and Water Content in Rat Brain during the Early Stage of Development of Cerebral Infarction. Brain, 97, 103-114. https://doi.org/10.1093/brain/97.1.103

[103] Lin, W., Paczynski, R.P., Venkatesan, R., He, Y.Y., Powers, W.J., Hsu, C.Y. and Haake, E.M. (1997) Quantitative Regional Brain Water Measurement with Magnetic Resonance Imaging in a Focal Ischemia Model. MRM, 38, 303-310. https://doi.org/10.1002/mrm.1910380221

[104] Lin, W., Venkatesan, R., Gurleyik, K., He, Y.Y., Powers, W.J. and Hsu, C.Y. (2000) An Absolute Measurement of Brain Water Content Using Magnetic Resonance Imagig in Two Cerebral Focal Ischemic Rat Models. Journal of Cerebral Blood Flow \& Metabolism, 20, 37-44. https://doi.org/10.1097/00004647-200001000-00007

[105] Venkatesan, R., Lin, W., Gurleyik, He, Y.Y., Paczynski, R.P., Powers, W.J. and Hsu, C.Y. (2000) Absolute Measurement of Water Content Using Magnetic Resonance Imaging: Preliminary Findings in an in Vivo Focal Ischemic Rat Model. MRM, 43, 46-150.

https://doi.org/10.1002/(SICI)1522-2594(200001)43:1<146::AID-MRM18>3.0.CO;2-L

[106] Skudlarek, J.W., Di Marco, C.N., Babaoglu, K., Roecker, A.J., Bruno, J.G., Pausch, M.A., O’Brien. J.A., Cabalu, T.D., Stevens, J., Brunner, J., Tannenbaum, P.L., Wuelfing, W.P., Garson, S.L., Fox, S.V., Savitz, A.T., Harrell, C.M., Gotter, A.L., Winrow, C.J., Renger, J.J., Kuduk, S.D. and Coleman, P.J. (2017) Investigation of Orexin-2 Selective Receptor Antagonists: Structural Modifications Resulting in Dual Orexin Receptor Antagonists. Bioorganic \& Medicinal Chemistry Letters, 27, 1364-1370. https://doi.org/10.1016/j.bmcl.2017.02.012

[107] Oi, N., Suzuki, M., Terauchi, T., Tokunaga, M., Nakatani, Y., Yamamoto, N., Fukumura, T., Zhang, M.-R., Suhara, T. and Higuchi, M. (2013) Synthesis and Evaluation of Novel for Positron Emission Tomography Imaging of Orexin 2 Receptors. Journal of Medicinal Chemistry, 56, 6371-6385. https://doi.org/10.1021/jm400772t

[108] Gao, M., Wang, M. and Zheng, Q.-H. (2016) Synthesis of [11C]MK-1064 as a New PET Radioligand for Imaging of Orexin-2 Receptors. Bioorganic \& Medicinal Chemistry Letters, 26, 3694-3699. https://doi.org/10.1016/j.bmcl.2016.05.083

[109] Valdearcos, M., Douglass, J.D., Roblee, M.M., Dorfman, M.D., Stifler, D.R., Bennett, M.L., Gerritse, I., Fasnacht, R., Barres, B.A., Thaler, J.P. and Koliwad, S.K. (2017) Microglial Inflammatory Signaling Orchestrates the Hypothalamic Immune Response to Dietary Excess and Mediates Obesity Susceptibility. Cell Metabolism, 26, 185-197. https://doi.org/10.1016/j.cmet.2017.05.015

[110] Dorfman, M.D., Krull, J.E., Douglass, J.D., Fassnacht, R., Lara-Lince, F., Meek, T.H., Shi, X., Damian, V., Nguyen, H.T., Matsen, M.E., Morton, G.J. and Thaler, J.P. (2017) Sex Differences in Microglial CX3CR Signaling Determine Obesity Suscepti- 
bility in Mice. Nature Communication, 8, 14556.

https://doi.org/10.1038/ncomms14556

[111] Auffray, C., Fogg, D., Garfa, M., Elain, G., Join-Lambert, O., Kayal, S., Sarnacki, S., Cumano, A., Lauvau, G. and Geissmann, F. (2007) Monitoring of Blood Vessels and Tissue by Population of Monocytes with Patrolling Behavior. Science, 317, 666-670. https://doi.org/10.1126/science.1142883

[112] Dorgham, K., Ghadiri, P., Hermand, P., Rodero, M., Poupel, L., Iga, M., Hartley, O., Gorochov, G., Combadiere, C. and Deterre, P. (2009) An Engineered CX3CR1 Antagonist Endowed with Anti-Inflammatory Activity. Journal of Leukocyte Biology, 86, 903-911. https://doi.org/10.1189/jlb.0308158

[113] Dorgham, K., Cerini, F., Gartner, H., Melotti, A., Rossitto-Borlat, I., Gorochov, G. and Hartley, O. (2016) Generating Chemokine Analogs with Enhanced Pharmacological Properties Using Phage Display. Methods in Enzymology, 750, 47-72. https://doi.org/10.1016/bs.mie.2015.09.014

[114] Thal, D.M., Vuckovic, Z., Draper-Joyce, C.J., Liang, Y.-L., Glukhova, A., Christopoulos, A. and Sexton, P.M. (2018) Recent Advances in the Determination of G Protein-Coupled Receptor Structures. Current Opinion Structural Biology, 51, 28-34. https://doi.org/10.1016/j.sbi.2018.03.002

[115] Ridderstad Wollberg, A., Ericsson-Dahlstrand, A., Jureu, A., Ekerot, P., Simon, S., Nilsson, M., Wiklund, S.-J., Berg, A.-L., Ferm, M., Sunnemark, D. and Johansson, R. (2014] Pharmacological Inhibition of Chemokine Receptor CX3CR1 Attenuates Disease in a Chronic Relapsing Rat Model of Multiple Sclerosis. PNAS, 111, 5409-5414. https://doi.org/10.1073/pnas.1316510111

[116] Seidel, L., Zarzycka, B., Zaidi, S.A. and Katrich, V. (2017) Structural Insight into the Activation of a Class B G-Protein-Coupled Receptor by Peptide Hormones in Live Human Cells. ELife, 6, e27711. https://doi.org/10.7554/eLife.27711

[117] Shaham, Y. and de Wit, H. (2016) Lost in Translation: CRF1 Receptor Antagonist and Addiction Treatment. Neuropsychopharmacology, 41, 2795-2797.

https://doi.org/10.1038/npp.2016.94

[118] Spierling, R. and Zorilla, E.P. (2017) Don't Stress about CRF: Assessing the Translational Failures of CRF1 Antagonists. Psychopharmacology, 234, 1467-1481. https://doi.org/10.1007/s00213-017-4556-2

[119] Howerton, A.R., Roland, A.V., Fluharty, J.M., Marshall, A., Chen, A., Daniels, D., Beck, S.G. and Bale, T.L. (2014) Sex Differences in Corticotropin Releasing Factor Receptor-1 Action within the Dorsal Raphe Nucleus in Stress Responsivity. Biological Psychiatry, 75, 873-883. https://doi.org/10.1016/j.biopsych.2013.10.013

[120] Lodge, N.J., Li, Y.-W., Chin, F.T., Dischino, D.D., Zoghbi, S.S., Deskus, J.A., Mattson, R.J., Imaizumo, M., Pieschl, R., Molski, T.F., Fujita, M., Dulac, H., Zaczek, R., Bronson, J.J., Maco, J.E., Innis, R.B. and Pike, V.W. (2014) Synthesis and Evaluation of Candidate PET Radioligands for Corticotropin Releasing Factor Type 1 Receptor. Nuclear Medicine and Biology, 41, 524-535. https://doi.org/10.1016/j.nucmedbio.2014.03.005

[121] Stehouwer, J.S., Bourke, C.H., Owens, M.J., Voll, R.J., Kilt, C.D. and Goodman, M.M. (2015) Synthesis, Binding Affinity, Radiolabelling and MicroPET Evaluation of 4-(2-Substituted-4-Substituted)-8-(Dialkylamino)-6-Methyl-1-Substituted-3,4-Dihy dro-pyrido-[2,3-b]Pyrazine-2[1H]-ones as Ligands for Brain Corticotropic Releasing Factor Receptor Type 1 (CRF1) Receptors. Bioorganic \& Medicinal Chemistry Letters, 25, 5111-5114. https://doi.org/10.1016/j.bmcl.2015.10.010

[122] Hartz, R.A., Ahuja, V.T., Zhuo, X., Mattson, R.J., Denhardt, D.J., Deskus, J.A., 
Vrudhula, V.M., Pan, S., Ditta, J.L., Shu, Y.-Z., Grace, J.E., Lentz, K.A., Lelas, S., Li, Y.-W., Molski, T.F., Krishnananthan, S., Wong, H., Quian-Cutrone, J., Schartmann, R., Denton, R., Lodge, N.J., Zaczek, R., Macor, J.E. and Bronson, J.J. (2009) A Strategy to Minimize Reactive Metabolite Formation: Discovery of (S)-4-(1-Cycloprpopyl-2-Methoxyethyl)-6-[6-(Difluoromethoxy)-2,5Dimethylpyridine-3-ylAmino] -5-oxo-4,5-Dihydropyrazine-2-Carbonitrile as a Potent Orally Bioavailable Corticotropin Releasing Factor-1 Receptor Antagonist. Journal of Medicinal Chemistry, 52, 7653-7668. https://doi.org/10.1021/jm900716v

[123] Hartz, R.A., Vrudhula, V.M., Ahuja, V.T., Grace, J.E., Lodge, N.J., Bronson, J.J. and Macor, J.E. (2017) Synthesis and Evaluation of Prodrugs of Corticotropin Releasing Factor 1 (CRF) Receptor Antagonist BMS 665053 Leading to Improved Oral Bioavailability. Bioorganic \& Medicinal Chemistry Letters, 27, 1360-1363.

https://doi.org/10.1016/j.bmcl.2017.02.015

[124] Poel van der, M., Ulas, T., Mizee, M.R., Hsiao, C.-C., Miedema, S.S.M., Schuurman, A.K.G., Heider, B., Tas, S.W., Schultze, J.L., Hamann, J. and Hiutinga, I. (2019) Transcriptional Profiling of Human Microglia Reveals Grey-White Matter Heterogeneity and Multiple Sclerosis-Associated Changes. Nature Communications, 10, Article No. 1139. https://doi.org/10.1038/s41467-019-08976-7

[125] Ayata, P., Badimon, A., Strasburger, H.J., Duff, M.K., Montgomery, S.E., Loh, Y.H., Ebert, A., Pimenova, A.A., Ramirez, B.R., Chan, A.T., Sullivan, J.M., Purushothaman, I., Scarpa, J.R., Goate, A.M., Busslinger, M., Shen, L., Losic, B. and Schaefer, A. (2018) Epigenetic Regulation of Brain Region-Specific Microglia Clearance Activity. Nature Neuroscience, 21, 1049-1060. https://doi.org/10.1038/s41593-018-0192-3

[126] Sawicki, C.M., Kim, J.K., Weber, M.D., Faw, T.D., McKim, D.B., Madalena, K.M., Lerch, J.K., Basso, D.M., Humeidan, M.L., Godbout, J.P. and Sheridan, J.F. (2019) Microglia Promote Increased Pain Behavior through Enhanced Inflammation in the Spinal Cord during Repeated Social Defeat Stress. Journal of Neuroscience, 39, 1139-1149. https://doi.org/10.1523/JNEUROSCI.2785-18.2018

[127] Majer, A., Medina, S.J, Sorensen, D., Martin, M.J., Frost, K.L., Phillipson, C., Manguiat, K. and Booth, S.A. (2019) The Cell Type Resolved Mouse Transcriptome in Neuro-Enriched Brain Tissues from the Hippocampus and Cerebellum during Prion Disease. Scientific Reports, 9, Article No. 1099. https://doi.org/10.1038/s41598-018-37715-Z

[128] Franco-Bocanegra, D.K., McAuley, C., Nicoll, J.A.R. and Boche, D. (2019) Molecular Mechanisms of Microglial Motility: Changes in Ageing and Alzheimer's Disease. Cells, 8, 639. https://doi.org/10.3390/cells8060639

[129] Dorand, R.B., Benson, B.L., Huang, L.F., Petrosiute, A. and Huang A.Y. (2019) Insights from Dynamic Neuro-Immune Imaging on Murine Immune Response to CNS Damage. Frontiers in Neuroscience, 13, 737. https://doi.org/10.3389/fnins.2019.00737

[130] Araki, K.Y., Sims, J.R. and Bide, P.G. (2007) Dopamine Receptor mRNA and Dopamine Expression in the Mouse Corpus Striatum and Cerebral Cortex in the Preand Postnatal Development. Brain Research, 1156, 31-45. https://doi.org/10.1016/j.brainres.2007.04.043

[131] Ganz, M., Feng, L., Demant-Hansen, H., Beliveau, V., Svarer, C., Knudsen, G.M. and Greve, D.N. (2017) Cerebellar Heterogeneity and Its Impact on PET Data Quantification of 5 HT-Receptor Radioligands. Journal of Cerebral Blood Flow \& Metabolism, 37, 3243-3252. https://doi.org/10.1177/0271678X16686092 


\section{Abbreviations}

BBB: Blood-brain-barrier

BSCB: Blood-spinal cord-barrier

BCRP: Breast cancer resistance protein

CRFR1: Corticotropin releasing factor receptor 1

CX3CL: Chemokine CX3C, Fractalkine

CX3CR: Chemokine CX3C receptor, Fractalkine receptor

DORA: Dual orexin receptor antagonist

EAE: Experimental autoimmune encephalitis

ECD: Extracellular domain

GPCR: G protein-coupled receptor

IL-1 $\beta$ : Interleukin- $1 \beta$

NPY: Neuropeptide Y

OXR: Orexin receptor

PET: Positron emission tomography

Pgp: Permeability glycoprotein

REM: Rapid eye movement

SORA: Selective orexin receptor antagonist

TCC: Trigeminal cervical complex

5TM: Containing 5 transmembrane domains

7TM: Containing 7 transmembrane domains

TMD5: Fifth transmembrane domain

TMD7: Seventh transmembrane domain

TSPO1: Mitochondrial translocator protein $(18 \mathrm{kDa})$, subtype 1

US28: Cytomegalovirus-encoded chemokine receptor homologue 